\title{
Neoliberalism in the Information Age, or Vice Versa? Global Citizenship, Technology, and Hegemonic Ideology
}

\author{
Robert Neubauer
}

\author{
School of Communication, Simon Fraser University \\ K9671-8888 University Drive \\ Burnaby, BC \\ Canada V5A 156
}

\begin{abstract}
Contingent as they are upon technological globalization, contemporary notions of global citizenship tend to run parallel to theories of 'post-industrialism' and 'information society'. This paper problematizes this relationship by delineating the connections between 'informationist' theory and neoliberal ideology, which together have laid the ideational foundations for a reordering of the global political economy over the past 40 years in favor of global capital. Drawing on the work of Antonio Gramsci, this paper argues that information-age theories have served to facilitate the neoliberal project, obscuring behind a veil of teleological inevitability and technological determinism the political transformations which make global neoliberalism possible, even while prescribing the technological innovations which make such transformations technically feasible. Crucially, in eroding national sovereignty over trade and labour laws, capital flows, and fiscal and monetary policy, the ascent of 'informational neoliberalism' has served to undermine traditional citizenship in favor of market discipline and neoliberal hegemony.
\end{abstract}

Keywords: Global Citizenship, Globalization, Neoliberalism, Neo-Gramscian, Information Age, Information Society, PostIndustrialism, Political Economy, Ideology, Hegemony.

Acknowledgement: The author of this article would like to acknowledge the advice and support of Professor Rick Gruneau and Ass. Professor Shane Gunster of the School of Communication at Simon Fraser University. The advice and support they offered the author was critical to the development of this paper. An earlier version of this paper was presented at the annual conference of the International Association of Media and Communications Research in July 2010, and the feedback received there was also crucial to the final completion of this paper.

Notions of citizenship have undergone a major shift in the age of globalization. In these new discourses, a growing recognition of global interconnectedness has emerged alongside a transnational activism in which disparate networks of citizens leverage information communications technology to exercise a global political agency. The result, according to the proponents of this discourse, is a global citizenship in which an emerging transnational citizenry is empowered by technology to usher in meaningful social change on a scope previously unimaginable.

And yet, notes Nick Dyer-Witheford, "[o]n the eve of the 21 st century the only revolution spoken of in advanced capitalism is the information revolution"(1999, p. 15). This would hardly surprise theorists of post-industrialism and the information age (referred to in this paper as "informationists"). As direct descendants of Daniel Bell's writings on The End of Ideology, they have long painted utopian visions of an era in which political-economies of symbolic data embedded in global telecommunication networks eliminate the inequities of the industrial age. This new world, argue the informationists, has rejected material scarcity in favor of knowledge-based economic growth, negating the class conflicts of the industrial era along with the ideologies fuelled by them.

Political economists, especially those of the Marxist variety, have pointed out that the changes informationists describe are in fact associated with a global reorganisation of capitalism that has been occurring since the 1970 s, and that as such informationism represents at best a partial explanation, or at worst an ideological smokescreen, for these broader political-economic transitions. Unfortunately, some of these critics have at times substituted the technological determinism of 
informationism with an economic determinism that can seem every bit as teleological as the theories they critique. Alternatively, this paper argues that the resurgence of capitalism and the subsequent rejuvenation of global class power since the1970s are best described neither by technological determinism nor a self-propelled reorganization of capitalism, but rather through the hegemonic consolidation of a very specific ideology. This ideology is neoliberalism, and its connection with informationism is as profound as its implications for democratic citizenship are corrosive. Both informationism and neoliberalism emerged from mainstream think-tank's and universities; both were funded and propagated by powerful corporate and government actors; and both seek to paint the emergence of global neoliberalism as inevitable yet desirable, while simultaneously prescribing the institutional, political, and economic reforms which make this system feasible. In this way, the parallel rise of these two ideological constructs since the 1970s have helped orchestrate and legitimate a reorganization of global hegemony organized around neoliberal regimes of flexible accumulation. In fact, the two ideologies have been so mutually supportive of each other that they are increasingly conflated in mainstream discourse, emerging to form a single ideological system: informational-neoliberalism. In this sense these ideas have helped form the ideological front of a hegemonic global neoliberal bloc which at its core undermines the very possibility of meaningful democratic citizenship.

\section{Global Citizenship}

The core ideas behind global citizenship are not new. They draw on traditional notions of citizenship which, in the words of Darren O'Byrne, incorporate a "balance between membership, rights, duties, and participation" in political society $(2003$, p. 235$)$. Notions of democratic citizenship expand on those core components to prioritize meaningful participation in the public affairs of the nation, mediated through a variety of public institutions (Battistoni, 1997), (Mettler and Soss, 2004), (Hemingway, 2004). This may occur through direct selection of policy alternatives, as in direct democracy, or by proxy though selection of elected representatives which carry out the citizenry's interests, as in representative democracy. Regardless, participation in the public institutions of society is a central component of democratic citizenship.

However, global citizenship breaks with some of the fundamental assumptions of democratic citizenship, at least as envisioned at the national level. Hans Schattle points out that the idea of world citizenship "reflects an ancient tradition - the cosmopolitan tradition - that dates back at least as far as ancient Greece" (2008, p. 1-2). Yet the contemporary resurgence of global citizenship is mostly contingent on processes of globalisation which makes possible "political activism across borders" enabled by "global platforms of digital communication". As Nancy Stefanik points out, these are "the same technologies which [have come to] support the global economy" (p. 152).

O'Byrne argues that these same processes of globalisation have undermined the sovereignty of the nation state, clearing the path for a new global politics (2003, p. 102). This new politics is increasingly divorced from "contractarian tradition[s]" of citizenship that "emphasize the role of the citizen as the bearer of rights and duties in relation to the political state" (p. 125-127). As such, citizenship is no longer found "within the state-citizen relationship but within ...the emergent cosmopolitan public sphere." Instead of a "citizenship... based around active participation in the political sphere", global citizenship is defined as a "performative" process exercised through technologically enabled discourse. Therefore, democratic participation is no longer contingent upon "universal... access to the decision-making process" of the state, but rather upon "the control of information" in a globalised civil society.

It would seem that the theoretical frameworks of O'Byrne and other global citizenship theorists owe much to informationist ideology. This is a critical point given that informationism as both ideological construct and material practice is itself intertwined with a global neoliberal project which by its very essence undermines any meaningful practice of democratic citizenship. However, before we can unpack informationism and neoliberalism as ideological constructs, we must look more closely at the notion of ideology itself. 


\section{Ideology, Intellectuals, and Hegemony}

In the essay Feuerbach, Marx famously argued that the "ruling ideas" of a society originate with the "the class which has the means of material production at its disposal" (Marx and Engels, 2006, p. 10). Dominant ideologies therefore tend to reinforce the "ideal expression of the dominant material relationships" of an era (Marx, 1965, p. 14). This does not imply a conspiratorial, conscious attempt to promote one's own interest; more likely the ruling classes simply come to believe that "the special conditions of [their] emancipation are the general conditions though which alone modern society can be saved" (Bell, 1960, p. 396).

Antonio Gramsci would further develop these arguments in his conception of hegemony, a form of social domination mutually based on both coercion and consent (2005). In doing so, he identified in Marx's superstructure two major components: "civil society" (the church, the universities, the media, etc) and "political society" (formal government apparatus) which together constituted both the State and the broader structures of hegemony (p. 12). Though Liberalism had bred a form of "Stateolatry" that limited conceptions of the State to formal government (p. 268), Gramsci argued that Civil Society actually helped develop formal government by producing "historically organic ideologies ...necessary to a given structure" (p. 376). Therefore the State could be understood as resulting from the organic relations between political society and civil society, with both constituting each other through processes of articulation and legitimation (pp. 243-269). In this way civil society -the universities, mass media, and other ideational actors - works alongside formal government to construct and maintain the hegemonic "bloc", (p. 366) which can be defined as the dominant social formation composed of different classes, productive forces, institutions, social actors, and ideologies. Ideologies produced in the privileged civil society institutions of the bloc are especially important, since these come to constitute the bloc's "ideological 'front (1985, p. 289), best understood as the complex of ideas, values, and ideologies which together form the "common sense" of society and provide a bloc with "an element of ... moral and intellectual order" (Pozzolini, 1970, p. 113).

Chief among those who maintain the hegemonic order are the "organic intellectuals" of the dominant social formation (Gramsci, 2005, 6), who operate within the aforementioned institutions to "direct the ideas and aspirations of the class to which they organically belong" (Hoare and Smith, in Gramsci, 2005, 3). According to Gramsci, under capitalism these "organic intellectuals" were increasingly taking the form of technocrat-philosophers who embraced a more "active participation in practical life", both as material organisers of capitalist modes of accumulation and as "permanent persuaders" of the public (p. 5). Furthermore, they were likely to consider themselves autonomous even while developing the ideological front which legitimized the bloc's hegemony and delineated its strategies, values, and forms (pp. 5-14). In this context, it is ironic then that the ideas which American sociologist Daniel Bell explained in his writings on the End of Ideology and the coming of Post-Industrialism - ideas which formed the basis of informationist theory - would help constitute the ideological front of global hegemony in the $21^{\text {st }}$ century.

\section{The End of Ideology, Post-Industrialism and the Information Society}

In 1960 Daniel Bell published The End of Ideology, in which he argued that the economic growth of the post-war period and its subsequent redistribution through collective bargaining and state welfarism had exhausted ideological conflict in America (Dyer-Witheford, 1999, p. 16). Bell noted that the appeal of radical ideology was greatest "in societies where awareness of class differences run deep [and] expectations of social advancement outstrip possibilities"- conditions no longer present in the affluent west (1960, p. 31). Utilising a Schumpeterian model of economic growth, he stressed that technological development represented an "uncharted sea" of opportunities for wealth creation and redistribution (p. 38). The West had seen "the law of increasing misery ... refuted by...tremendous advances of technology" which allowed for wealth accumulation on a scale never before seen (p. 283). This unprecedented economic surplus was being redistributed through trade unionism and the institutions of the welfare state, undermining the appeal of revolutionary change (p. 214-219). Furthermore, union membership had reached a plateau, with the rise of white collar 
and technical professions increasingly producing a workforce which neither organised nor identified as a class. In short, the "proletariat [was] being replaced by a salariat" (p. 221). The result was that "[t]hough ideology in the $19^{\text {th }}$ and early $20^{\text {th }}$ century had much force", (p. 402) technologically induced economic growth, institutionalised wealth redistribution, and occupational change had led to "the end of ... revolutions" in the West (p. 406).

The social conflict of the 1960s and early 1970s made claims to an "end of ideology" seem anachronistic. Regardless, Bell's publication of the Coming of the Post Industrial Society in 1973 further refined these ideas (Kumar, 1995, pp. 1-3). He described in detail the decline of traditional manufacturing in the West and the corresponding expansion of the knowledge and service industries, arguing that in this new mode of production, theoretical knowledge was replacing labour and raw materials as the 'strategic' economic resource. Bell's central assertion that "post industrial society is an information society, as industrial society is a goods producing society" would form the basis of what came to be known under varying theoretical iterations as the "information society", the "technetronic society", the "information economy" and other related concepts of informationism. Zbigniew Brzezinski wrote of the 'technetronic society' in which the "new technology of electronic communications [ushered in] a new age" (Dyer-Witheford, 1999, p. 9); Japanese writers such as Yonei Masuda theorised an 'information society' in which information became the core organising force of society (Beniger, 1986, p. 7); the economists Fritz Machlup and Marc Porat charted the rise of the information economy' (Kumar; 1995, p. 11); Herman Kahn and Antony Weiner elaborated on similar themes in their 'year 2000' scenarios (Dyer-Witheford, 1999, p. 17); and writers such as Alvin Toffler and John Naisbit popularised these theories in best-selling books" (Kumar, 1995, p. 9). Notions of the 'information age' soon gained acceptance not just in mainstream social science, but also think-tanks, government offices, corporate boardrooms, and mainstream media accounts. Today 'informationism' is one of the most powerful ideas of our time, structuring the way society understands the present and envisions the future. While its multiple iterations by no means agree with each other on all points, there are significant commonalities.

\subsection{Knowledge as Resource}

According to Bell, post-industrialization involved a demonstrable "changeover from a goods producing society to an information and knowledge society" in which "knowledge and information" becomes the "strategic resource" of economic production, eclipsing land, physical capital, and labour (1973, p. 487). To prove this he drew upon the economic calculations of Fritz Machlup (and later Marc Porat) that showed "informational activities" such as research, marketing, and teaching rapidly overtaking industrial manufacturing as a portion of US GNP. Bell also noted that the early $20^{\text {th }}$ century had seen an explosion of scientific knowledge and with it an increasingly important role for applied science in industries such as chemicals, computers, and telecommunications (p. 180). Later informationists seized on this idea, arguing that "techno-scientific knowledge" was now the "crucial resource" of economic development (Dyer-Witheford, 1999, pp. 23-24). Alvin Toffler was far from alone in arguing that the "generation of wealth increasingly depends on the information economy", with the "exchange and manipulation of symbolic data" gaining in importance relative to "material processing". As John Naisbit put it, the rise of telecommunications, advanced research, and the service economy meant that the West now "mass-produced information the way [it] used to mass-produce cars" (Kumar, 1995, p. 12).

\subsection{Decline of the Built and the Builders}

Informationists argued that the rise of the information economy would see economic growth increasingly decoupled from industrial manufacturing (Toffler, 1980, p. 141). According to Bell, the "new industries of the 1970s" were the knowledge-based high-technology industries (polymers and plastics, electronics and optics, chemicals and synthetics, aerospace and communications) and the services (retail, banking, finance, real estate, insurance, transportation, utilities, health, education, research, and consumer services) (1973, p. 153), with a subsequent decline in traditional manufac- 
turing. Later writers agreed, though would come to put more emphasis on entertainment, telecommunications, computers, and (eventually) the internet (Toffler, 1980, p. 2).

These changing modes of production were altering the occupational makeup of the economy. Bell argued that the new economy would rely less on the semi-skilled factory worker of industrialism and more on the professionals, technicians, and knowledge workers of the high-tech industries and the service economy (1973, p. 117). He used the calculations of Machlup to show that by 1975 professionals, technicians, and knowledge workers would make up $25 \%$ of the US workforce - with more still employed in the service sector - whilst the number of industrial workers steadily declined

(p. 215). Later informationists tracked the continuing proliferation of service industry professions such as salesmen, architects, designers, consultants, financial workers, insurance agents, and lawyers (Toffler, 1980, p. 195), which together with the computerization of manufacturing (Kumar, 1995, p. 21) further depressed industrial employment.

As a result, the importance of organized labour was in decline. As Dyer-Witheford explains, informationists saw a unified "industrial proletariat... replaced by a diverse array of knowledgeintensive professionals", which given their high-living standards and occupational fragmentation had neither the desire nor the ability to organise as a class (1999, p. 15-16). Such trends represented a shift away from collective, class-based solidarities and towards a radical, transcendent individualism. Moreover, since economic growth was now contingent on the use of "intelligent machines", Marx's "labour theory of value" was obsolete. In the information age, "knowledge, not labour, is the source of power".

\subsection{Decline of the State}

The same processes that undermined organized labor were "drastically shrink[ing] the power of the individual nation state", which writers like Toffler claimed was "being squeezed by viselike pressures from above and below" (1980, p. 328). Like trade unions, national governments were ill equipped to "respond flexibly to the rapid demassification of society", as the transcendent individualist of the information age found little use for the 'one-size-fits-all' approaches of modern states.(p. 333-335). Unlike businesses which increasingly turned towards modes of flexible accumulation, national governments continued "to impose uniform, standardized policies designed for a mass society on increasingly divergent and segmented publics". The state was being further marginalized as "tightened economic linkages between nations ma[de] it virtually impossible for any individual national government... to manage its own economy independently". Government regulation was even counterproductive; given that the new economy "require[d] the development of a highly ramified, sensitive, wide open....information system", any "attempts by individual nations to dam up data flows may interfere with... their own economic development". As the informationist Kenichi Ohmae famously declared, the information age was the age of the "borderless world" (Mosco, 2004, p. 87).

\subsection{One Planet, One System}

Importantly, then, informationists increasingly saw their revolution as "planetary in scale" (DyerWitheford, 1999, 25-26). While Bell had described post-industrial society as a first world phenomenon, later theorists identified a technologically-induced "tendency toward a unified global economy" through the spread of computerisation and telecommunications. These technologies were linking markets, producers, and consumers all over the world into an integrated economic system that could function in real time across national and geographic boundaries. In other words, the information revolution was creating what we know today as economic globalisation. All nations were assumed to benefit from this system; some theorists argued that "rapid computerisation" would allow developing countries to bypass industrialism altogether, while others believed that the wealth generated by global commerce would raise living standards in all nations. Most strikingly, this globally interconnected system was giving rise to a "planetary consciousness" which caused citizens to think of themselves as members of a global entity (Toffler, 1980, p. 336). 


\subsection{The Rise of Information, the End of Ideology}

Bell had argued in his End of Ideology that technologically produced wealth, institutionalised redistribution, and the break-up of traditional class structures had suffocated revolutionary ideologies like communism and fascism, leaving capitalist democracy as the sole contender. Later informationists downplayed Bell's faith in the welfare state, emphasising the information age's capacity for individualistic transcendence from the 'modernist' collective institutions of state, labor, and corporation. However, their conclusions generally followed Bell in envisioning a future beyond ideological conflict.

Many informationists saw the new society as positively utopian (Kumar, 1995, p. 14). If, as Toffler claimed, "the heavy-handed technologies of industry" had produced heavy costs for workers, the environment, and society as a whole, the "technologies for the future" would provide humane jobs and enough wealth for all $(1980$, p. 152). As knowledge, not labor or raw materials, was the paramount economic resource, material scarcity could be effectively mitigated through technological innovation. Also, as information workers enjoyed more creatively and financially satisfying employment than factory workers, they tended to regard ideological conflict as an aberration (DyerWitheford, 1999, p. 28). Furthermore, the withering of centralized institutions would give rise to a radically decentralized society in which all those with the means to transmit and manipulate information would be able to exercise power through technological 'neural networks'. The result, according to Toffler, was that the old ideologies had been "discredited, discounted, superseded, or subsumed into much larger and more powerful theories", namely those of informationism (1980, p. 289).

\section{The End of Ideology and the Rise of Neoliberalism}

Surely informationists have identified some profound systemic changes - no one denies that computers have changed our world, or that large scale shifts in the makeup of the workforce are empirical fact. But as Krishan Kumar writes, "what needs scrutiny is the central claim that all these changes add up to a new social order" (1978, p. 199). Or as Theodore Roszak writes more pointedly, "people who have no clear idea what they mean by information or why they should want so much of it are nonetheless prepared to believe that we live in an information age" (Kumar, 1995, p. 7).

As Douglas Kellner points out, informationism "exaggerate[s] the role of knowledge and information..., occludes the connections between industrial manufacturing and emergent hi-tech industries," and downplays "the role of capitalist relations of production, corporate ownership and control, and hegemonic configurations of corporate and state power" (2003, p. 22-23). In reality, it is quite problematic "to characterize knowledge or information as the organizing or axial principles of a society still constructed around the accumulation of capital and maximization of profit".

Numerous Marxists have pointed out that many of the societal changes associated with informationism - the breakdown of traditional manufacturing; the rise of the service/knowledge sectors; the ascension of global telecommunications networks and symbolic economies; and the decline of organized labour - are associated with an ongoing restructuring of global capitalism that has sought to overcome crises of accumulation emerging in Keynesian and/or Fordist political economies in the 1970s (Kumar, 1995, p. 32-60). Related theories of post-fordism, regulationism, flexible accumulation, or "New Times" all challenge the technological determinism of informationism by situating its socio-technological changes within a transformation of modes of regulation and production in the capitalist world system. Unfortunately these critics seem to replace technological determinism with their own brand of economic determinism in which capitalism seems to reorganize its own structural features, utilizing or perhaps propelled by new techno-organizational forms to overcome crisis. In this critique capitalism sometimes seems to have evolved on its own accord, and informationism is merely its updated ideological expression.

It may be more fruitful to look at the ideological basis of this material transformation. As Gramsci argued, a hegemonic ideology is more than just a collection of ideas that justify social relations; nor 
is it merely the normative, ontological, and epistemological framework around which social reality is understood and acted upon. A hegemonic ideology is this, but it is also a blueprint for the material organization of society, and as such it is mutually constituted by the same social, political, and economic institutions it serves to shape. We can better position informationism in an ideological front by charting the rise of another powerful ideology which has fundamentally reshaped the material organisation of our society over the past 40 years. This would be neoliberalism, the radical free market doctrine that promotes widespread deregulation, privatisation, unrestricted financial/capital flows, and the erosion of organised labour as the only sustainable route to economic development. This idea is so pervasive and has so profoundly reshaped the world system that it easily qualifies as a core component of the ruling ideological front. It has also, we shall see, critically undermined the capacity for a meaningful citizenship at both the national and global level.

While neoliberalism's contemporary ascendancy has been widely commented on, less noticed has been the key role that informationism has played in its promotion. "Information", notes Roszak, "smacks of safe neutrality". It has therefore proven to be "the perfect starting point for a technocratic political agenda that wants as little exposure for its objectives as possible. After all, what can anyone say against information?(Webster, 2006, p. 24)" In painting utopian visions of the technologies without which global neoliberalism would be impossible, even while describing as teleologically inevitable processes which are in large part politically driven, informationism has vigorously promoted neoliberal ideology. However, before explaining the connections between informationism and neoliberalism, we must take a closer look at the latter's prescriptions, strategies, and goals as a dominant ideology.

\subsection{Neoliberal Recommendations}

David Harvey describes the essence of neoliberalism as the belief that "the social good will be maximised by maximising the reach and frequency of market transaction", with the normative foundation for the 'good life' arising from 'free' individuals exercising their personal liberty under a market system as entrepreneurs, workers, and consumers $(2005$, p. 3). The role of the state is therefore to facilitate capital accumulation, developing and maintaining the institutional basis of a 'free' market system underpinned by unfettered entrepreneurialism, strong property rights, and free trade (Harvey, 2005, p. 2). At the same time, the state is supposed to dismantle or undermine any possible barriers capital accumulation, especially those from interventionist governments, democratic publics, civil society, or organized labour. In this sense, the neoliberal state may be forced to embrace anti-democratic forms of rule in the service of a market system ostensibly underpinned by freedom and liberty.

To that end, neoliberal advocates argue for a diverse suite of free market reforms, including the privatisation of public utilities and enterprises, wholesale deregulation, flexible labour laws, unrestricted financial and capital flows across borders, and unfettered access to markets, and the removal of 'protectionist' barriers to commerce, all of which are meant to increase economic growth which is then redistributed through market mechanisms (pp. 64-67) Deprived of its traditional regulatory role under Keynesian-Fordist regimes of accumulation, the state moves away from interventionist policy to become what Bob Jessop terms a "Schumpeterian workfare state" (Amin, 1997, p. 27). In this configuration, the state's chief responsibility is the promotion of "market innovation in open economies", subordinating "social policy to the needs of labour market flexibility and/or the constraints of international competition". In short, the neoliberal agenda has as its central goal the dismantling of nationally oriented Keynesian-Fordist modes of accumulation which underpinned the political economy of the postwar era, and their replacement with a global regime of flexible accumulation underpinned by a corresponding neoliberal regulatory apparatus (Robinson, 2008; 2004).

\subsection{Neoliberal Rising}

In charting the rise of neoliberal hegemony, it is important to distinguish between the different 'aspects' or 'instances' of neoliberalism. In its first instance, neoliberalism reveals itself as an ideology 
- a loosely coherent worldview and corresponding set of beliefs based on a revival of neoclassical economics (Harvey, 2005; Robinson, 2008; 2004). As ideology, neoliberalism was purposely developed by an epistemic community of 'organic intellectuals' as an alternative to Keynesian theory and state-led development in general. Through their efforts, this ideology came to be institutionally consolidated as neoliberalism's second instance - a globalised regime of flexible accumulation organized around neoliberal principles.

In other words, neoliberalism's institutional consolidation was not spontaneous; it involved decades of planning and organisation on the part of radical economists, business leaders, and government officials (Harvey, 2005, pp. 43-44). Much of the intellectual basis for the movement emerged from the Mont Pelerine Society, an association of intellectuals (including the economist Milton Friedman) that organised around the ideas of libertarian philosopher Frederick von Hayek. By the 1970s their ideas were taking hold in the most powerful institutions of corporate America. In 1971, for instance, neoliberal advocate and soon-to-be US Supreme Court Justice Lewis Powel wrote a secret letter to the American Chamber of Commerce arguing that "the time had come... for the resources... of American businesses to be marshalled against those who would destroy it", encouraging the Chamber to lead an ideological assault upon universities, schools, the media, and the courts (p. 43). Within 10 years the Chamber of Commerce had more than doubled its corporate membership, and alongside the National Association of Manufacturers had directed huge sums of money towards congressional lobbying and the dissemination of neoliberal propaganda (pp. 4344). In 1972 these organisations helped establish the Business Roundtable, an organisation of American CEOs which, Harvey explains, became a "centerpiece of collective pro-business action." The same period saw the rise of neoliberal think tanks such as the Heritage Foundation, the Hoover Institute, the Centre for the Study of American Business and the American Enterprise Institute, all of which received lavish corporate financial backing. One of these groups' main activities was to produce propaganda extolling the virtues of market fundamentalism. Along with the 'charitable' foundations of several notable business families, they helped to publish and promote works of radical neoliberal thought, including Robert Nozick's popular Anarchy State Utopia and Milton Friedman's Free to Choose. Throughout the decade it is estimated that US corporations spent $\$ 900$ million annually on these lobbying and propaganda efforts. It was money well spent.

Harvey notes that:

"advocates of the neoliberal way now occupy positions of considerable influence in education (universities and many 'think tanks') in the media, in corporate board rooms and financial institutions, in key state institutions (treasury departments, the central banks) and also in those international institutions such as the international monetary fund, the world bank, and the world trade organisation that regulate global finance and trade... Neoliberalism has, in short, become hegemonic as a mode of discourse... incorporated into the common-sense way many of us interpret, live in, and understand the world" (p. 3).

He does not exaggerate. The spread of neoliberal thought has successfully organised a global neoliberal regulatory regime in less than half a century. In 1971 the US government scrapped the Bretton Woods system of currency regulation and initiated floating exchange rates, a key neoliberal goal (p. 10), and throughout the decade would go on to successfully promote the liberalisation of credit markets in many countries (Peck and Tickell, 1997, p. 291). By 1982 the Reagan administration purged the last Keynesians from the IMF. Freed from their influence, the organisation consolidated its already infamous policies of 'structural adjustment', demanding that developing nations implement neoliberal reforms "such as cuts in welfare expenditures, more flexible labour market laws, and privatisation" in return for debt rescheduling (Harvey, 2005, p. 29). Institutional consolidation continued in the Clinton years, as a neoliberal "Wall Street-IMF-Treasury complex that came to dominate economic policy" pushed for neoliberal reforms and regional 'free trade' agreements in the US and abroad (p. 16). In 1995 the founding of the World Trade Organisation put further pressure on states to scrap any regulation, subsidy, or government service that could be seen as a barrier to neoliberal trade (p. 3). So pervasive was neoliberal thinking that by the mid 1990's its recommendations had come to be known, without a hint of irony, as "the Washington Consensus", 
with the IMF and World Bank broadly asserting that "the degree of neoliberalisation" in an economy was the fundamental measure of "a good business climate" (p. 16). In the words of Peck and Tickell, "neoliberalism [had become]...the new regulatory form" of the global political economy (Peck and Tickell, 1997, p. 282).

William Robinson has argued that this global institutional consolidation of neoliberal ideology represents the partial dismantling of nationally-oriented state-led development regimes in favour of a "Transnational State Apparatus" (TSA) dominated by globally-oriented capitalist interests, government officials, and civil society actors (2008). Together, these groups have used the TSA to develop, integrate, and maintain the neoliberal reforms which constitute globalised regimes of neoliberal flexible accumulation at both the national and transnational level, keeping with neoliberalism's primary vision of the state as a facilitator of capital accumulation. No monolithic entity, this "state" is constituted by the sometimes loose integration of both national and international components. Internationally, the TSA takes the form of regional and global institutions such as the World Bank and the WTO, as well as trade agreements like Mercosur and NAFTA which increasingly bind nations together in a single neoliberal political-economy (p. 196). However, many nation state institutions (especially ministries of finance and trade) are themselves partially subsumed into the TSA as they increasingly abandon traditional tasks of national development (regulating in favour of labour, funding social services, etc) in favour of policies of global flexible accumulation (trade integration, capital mobility, financial deregulation, labour flexibility, etc.) (p. 179). Critically, this new 'state' structure is structured so as to be insulated from national democratic publics, in keeping with neoliberalism's hostility to any democratic intervention in processes of capital accumulation.

\subsection{Neoliberal Goals}

If the political strategies of neoliberalism are easy to piece together in hindsight, so are the ultimate goals of its corporate proponents. By the 1970s, notes Dyer-Witheford, "profit rates in the old centers of accumulation [were] tumbling" as a result of industry regulation, the strength of organised labour, and the rise of social justice movements around the world $(1999,133)$. In this context, neoliberalism's institutional consolidation reveals itself in yet another instance - neoliberalism as a global class project to overcome capitalist crisis while revitalising upper-class power and capital accumulation on an international scale (Harvey, 2005), (Harvey, 2010), (Robinson, 2004), (Robinson, 2008). It did this by promoting the expansion of predatory financial industries, the disintegration of organised labour, the deconstruction of the Keynesian state apparatus and its Fordist modes of accumulation, and the amassing of the largest concentration of global wealth the modern world has ever seen. To this end, neoliberal reform has helped constitute a new transnationalisation of capitalist modes of production and their corresponding regulatory regimes, as national economies, states, class formations, and civil society networks have become increasingly integrated as component pieces in global circuits of capital accumulation and regulation (Robinson, 2004; 2008; Hope, 2009; 2010).

\subsubsection{Transnational Flexible Production}

At the core of the neoliberal class project is the attempted constitution of a global regime of flexible accumulation organized around transnationalised flexible production chains, just-in-time manufacturing, and intensified financialisation. As Robinson notes, this involves a shift from "global market integration to global productive integration", in which transnational capital develops external networks with a "myriad of firms" throughout the world, integrating them into "transnational production processes" (2008, p. 25). Globally, this has involved a sharp rise in Foreign Direct Investment alongside the growth of transnational corporate affiliates and interlocking directorates, cross-border mergers, and transnational ownership of capital shares. In this form of economic organization, the monolithic corporation of monopoly capitalism is superseded by models of flexible accumulation where firms become component pieces in complex networks of suppliers, producers, subcontractors, distributors, transporters, and financiers (p. 31). As we shall see, this type of transnationaly 
integrated flexible production is important for transnational capital's dual goals of disciplining organized labour and insufficiently cooperative nation-states.

\subsubsection{Financial Deregulation}

The deregulation and expansion of financial markets promoted by neoliberal institutions have been essential to the restoration of class rule. The new sources of accumulation that deregulation produces - innovations in securities, derivatives, and futures trading (Harvey, 2005, p. 145) - require no organised industrial workforce with which to share profits. Furthermore, Harvey notes that the advent of global financialisation has been remarkably predatory in nature, (p. 161) with the credit system becoming "the major modern lever for the extraction of wealth by finance capital from the rest of the population" $(2010,245)$. Predatory practices such as usurious credit card rates, foreclosures on businesses by the denial of liquidity at key moments, stock promotions, ponzi schemes, inflationary asset destruction and subsequent repurchase at bargain prices, asset-stripping through mergers and acquisitions, the promotion of population-wide debt peonage, the raiding of pension funds, and credit and stock manipulations have become all too common. Through these schemes financial elites have found themselves possessors of massive fortunes and near-unchallenged social, political, and economic power.

Importantly, global financial markets also make it far easier to coordinate an integrated system of transnationaly integrated flexible production and capital accumulation, shifting production from site to site with a speed previously unheard of (McGuian, 1999, p. 386). It has therefore never been easier to disinvest from a region and reinvest somewhere else, allowing corporations to bypass local tax rates, the demands of labour, and the rule of local governments.

Deregulated financial and credit markets also allow financial capital to instigate and manipulate financial crises in entire regions (Harvey, 2005, 162). This is precisely what happened in the financial crises of East Asia (1996), Mexico (1982, 1995), and Argentina (1995) (pp. 94-112). In some cases (Mexico), crisis was triggered by the raising of US interest rates, while in others (East Asia), collapse followed mass flight of foreign capital from unregulated financial markets, enabling investors to burst speculative bubbles they themselves had helped inflate. The common thread is that integration into global financial markets helped devalue local currencies (now embedded in floating exchanges) and instigate capital flight. This in turn led to soaring public debt, the withering away of foreign reserves, and the plummeting value of local assets which could now be snatched up for a song by foreign capital.

In Mexico, Argentina, and East Asia, the convergence of capital flight and skyrocketing debt gave the IMF leverage to demand further privatisation and deregulation, whilst urging the sale of now devalued assets to foreign capital, in some cases to the very same institutions which had provoked the crisis in the first place. The program of privatisation in Mexico pursued in the fallout of the 1982 financial crises saw the production of 17 billionaires who made their fortunes in the privatisation of banks, factories, telecommunication firms, and other public assets. Of the 30 banks privatised in this way, 24 were purchased by foreign concerns by 2000. Explain Wade and Veneroso, "financial crises have always caused transfers of ownership and power to those who ....are in a position to create credit" (p. 162). In the cases described above, the "combination of massive devaluations, IMF-pushed financial liberalisation, and IMF-facilitated recovery may...precipitate the biggest transfer of peacetime assets from domestic to foreign owners in the past 50 years anywhere in the world".

Meanwhile the regions in crisis suffer mass unemployment, erosion of purchasing power, and surging rates of urban poverty (pp. 94-112). The loss of national assets is accompanied by staggering levels of post-crisis debt, which can be leveraged by international lenders to demand even more neoliberal reforms,(pp. 94-112). This occurs even whilst speculative pressure from global financial markets results in further adoption of neoliberal reforms (Dyer-Witheford, 1999, p. 140; (Robinson, 2004; 2008; Harvey, 2005).

Though previously consigned to the semi-peripheral economies of the developing world, the enhancement of upper class rule through financial crisis has now come to roost in the West. Indeed, 
the political and economic fallout from the global collapse of 2008 has been predictably predatory in nature. Essentially, neoliberal deregulation and integration of global financial markets combined with global capital-hyper mobility to instigate a massive devaluation of global financial assets triggered by the bursting of a North American debt bubble - itself inflated in response to the long-term stagnation of working class income under flexible accumulation (Harvey, 2010; Bellamy-Foster and Magdoff, 2009; Hope, 2010; Thompson, 2010). Trillions of dollars of tax-payer money was then used to bailout the banking and finance sectors, often funded by government bonds payable to the very same financial institutions being rescued (Thompson, 2010). This money was largely used to buy up the worthless 'toxic waste' of the major financial institutions (Bellamy-Foster and Magdoff, 2009).

Notes Thompson, "no sooner had bail-out packages been negotiated than the financial markets began to exert pressure on benefactor governments to reduce their debt levels by cutting spending on public services" (2010). Any "failure to do so will doubtless result in financial trading driving up interest rates and destabilizing currencies". In Greece, Ireland, England and other nations, citizens now find themselves having issued massive bailouts to the financial elite only to be told by that same elite and its political allies that the resulting deficits now necessitate severe austerity measures. At the same time, bailout money is used not to aid homeowners at risk of foreclosure or other vulnerable groups. Rather, notes Harvey, "the banks are using the money, not to lend to anybody but to reduce their leveraging and buy other banks. They are busy consolidating their power" (2010, p. 31). Indeed, the current crisis has instigated a wave of mergers and consolidations in the US, leaving the financial industry more concentrated than ever before (Nolan and Zhang, 2010). To top it off, corporate and especially financial profits are riding high yet again, while the rest of the population lives with the reality of unemployment and the immediate threat of imposed austerity (Harvey, 2010, 11).

\subsubsection{Global Market Access}

Financial markets are not the only ones which neoliberals seek to penetrate and integrate. Cheaper global markets for raw resources are also established. Mexico's entry into NAFTA, for example, eliminated constitutional protection for communal agricultural lands. These ejidos were privatised and sold off at low prices to foreign concerns, in the process dislocating millions of peasants who flooded and further devalued local labour markets. Similarly, in his study of global resource extraction industries, Darryl Reed demonstrates that "in the last ten to fifteen years transnational [resource extraction] corporations ... have [increasingly] been shifting their operations from developed to developing countries", especially in Latin America and Africa (2002, p. 201). Fuelling this shift have been neoliberal policies of "trade and investment liberalization", as the "direct pressures from international financial institutions" and regional trade agreements force developing nations to "engage in regulatory bargaining" (offering tax breaks, environmental concessions, etc.) (p. 204). The result is that by 1995 "some 35 African countries had amended their mining regulations to make them more attractive to foreign investors," while in Latin America there has been a return to the low tax rates, lack of labor protections, and high corporate profits of the neo-colonial era (p. 206-213). The result is an "international race to the bottom" which has seen corporate profits surge and local conditions deteriorate (p. 220).

\subsubsection{Triumph Over Labour}

The weakening of organised labour, notes Harvey, is "a necessary precondition for neoliberalisation" and the establishment of flexible regimes of accumulation (2005, p. 116). This is because regional "advantage[s] to capitalists" diminish as labour costs rise (Harvey, 1982, p. 403) under a Keynesian welfare system (p. 427). Tired of heavy taxes, collective agreements, social and environmental regulations, and other barriers to profit, "capitalists may move... to new social environments where the 'human resources' are ...less costly to maintain". Wildly beneficial for capitalists has been the creation of a global unregulated labour market through the dismantling of state wel- 
fare provisions and the expansion of unregulated finance and trade as imposed by undemocratic institutions of the TSA (WTO/GATT, 'free trade' agreements such as NAFTA, etc) (Harvey, 2005, p. 168). By making it harder to impose tariffs on goods manufactured without collective bargaining agreements or health and safety regulations, even while paving the way for capital's global hypermobility, these regimes erode the competitive position of first world manufacturing. As developed regions compete with those without significant labour costs, they are forced to gut their own welfare state to ward off capital flight and disinvestment. In the end, the power of labour is severely undermined as capital exploits globally depressed labour costs to maximise profit.

As confirmed by numerous scholarly accounts, capital flight from the demands of organized labor in the advanced capitalist core has led to deindustrialisation, falling and/or stagnating wages, intensifying work, undermined job security, and a general erosion of welfare provisions (Dyerwitheford, 1999, p. 134-135; Robinson, 2004; 2008; Harvey, 2005; 2010). Meanwhile, capital takes advantage of the more 'competitive' labour of Mexican maquiladoras or Malaysian microchip factories, whose workers remain lowly paid, non-unionised, and exposed to dangerous conditions. Even the workers in these new industrial zones are not safe from the threat of disinvestment, as indicated by recent job losses in Mexico to countries like China with even cheaper labour and regulatory costs (Harvey, 2005, p. 164-169).

\subsubsection{Withering the Keynesian State}

Under neoliberalism, the role of the state is to create and preserve an institutional framework for maintaining a market system characterized by "entrepreneurial freedoms", "strong private property rights, free markets, and free trade", regardless of the will of democratic publics (Harvey, 2005, p. 2). Therefore a key goal of neoliberal reform is the dismantling of Keynesian developmental states in favor of neoliberal states integrated into a transnational state apparatus insulated from democratic participation. The ascendancy of neoliberalism over the past 40 years has therefore seen country after country dismantle its Keynesian regulatory apparatus while pursue a suite of common neoliberal reforms, including the elimination of capital controls; dismantling of social services and national regulatory apparatuses; mass privatizations; regressive taxation; abolishment of subsidies; and the regional and global integration of markets through free trade agreements and transnational regulatory bodies like the WTO (Robinson, 2004), (Robinson, 2008), (Harvey, 2005).

Though such actions are often undertaken voluntarily by neoliberal state reformers, "the structural power of the global economy....instills new forms of discipline on national states" which do not voluntarily submit to sufficient neoliberalisation (Robinson, 2008, p. 184-185). Much of this occurs through the institutional consolidation of the anti-democratic TSA, especially global regulatory financial institutions such as the IMF and the World Bank. For example, before the 1998 financial crisis the Asian 'tigers' of Malaysia, South Korea, and Thailand had maintained impressive rates of growth through protectionist policies such as restrictions on foreign ownership, selective blocking of imports, and continued state control of key industries (Klein, 2007, p. 267). The crisis - itself triggered by the neoliberal abandonment of capital controls - forced the desperate Tigers to turn to the IMF for credit. In return for emergency loans, the fund forced the Tigers to "strip [the] trade and investment protectionism and activist state intervention that were the key ingredients of the "Asian miracle", leading to sweeping privatizations, mass layoffs, and the breakup of the region's most powerful firms and their subsequent sale to foreign capital (p. 269). Though these reforms were deeply unpopular, Asia's manufactured credit crisis forced it to abide by IMF dictate.

Once structural adjustments are made, institutional coercion is hardly necessary to insulate the neoliberal bloc from democratic opposition. This is because unregulated global financial markets can impose their own policy preferences upon nations that are integrated into global circuits of flexible accumulation. As Robinson explains, "the threat of capital flight [has] now become the major mechanism through which transnational capital exercises structural power over local states and populations" (2008, p. 263). In this sense, private credit risk assessment agencies such as Standard and Poors Rating Group and Moody's Investor Service serve a privileged "gate keeper" function, given that a low rating can trigger capital flight. For example, in the run-up to the Brazilian 
presidential election in 2002, populist candidate Lula de la Silva ran on a fiercely anti-neoliberal platform of land redistribution, expansion of social programs, and renegotiation of the national debt (p. 266). In response, private rating agencies "shifted their recommendations against Brazil", causing global investors to pull billions of dollars out of the country and bringing Brazil to the brink of financial collapse. Lula was forced to radically alter his electoral platform, pledging to respect IMF adjustment policies and promising not to default on the country's debt.

This was not an isolated occurrence. In most Latin American countries "the neoliberal project advanced despite systematic ... mass opposition" (p. 273). During the 1980s and 1990s, countries throughout the region elected governments which ran on explicitly anti-neoliberal platforms (p. 276278). Once in office these governments quickly succumbed to dual pressures from financial markets and global regulatory bodies like the IMF and World bank, abandoning their campaign promises and adopting further neoliberal reforms. Given that these reforms were an explicit rejection of their democratic mandate, many administrations were forced to "govern by executive fiat, violating constitutional norms and individual civil rights". Tactics included ruling by executive decree (Menem's Argentina), declaring a state of siege (Bolivia), and even dissolving the legislature and seizing emergency powers (Fujimori's Peru). In most cases these governments were thrown out by an embittered electorate in subsequent elections, only to be replaced with new anti-neoliberal candidates who themselves "repeated the u-turn". In all of these cases integration into the neoliberal bloc proved to be deeply corrosive to democratic rule.

\subsubsection{Neoliberalism and Citizenship}

Given the preceding account, it seems self-evident that that the rise of neoliberal regimes of flexible accumulation represents a profound threat to any meaningful definition of democratic citizenship. The erosion of any serious participation on the part of the citizenry in the political and economic decisions of a society -the prime definer of democratic citizenship - is a core component of globalised neoliberalism. By evading the demands of organised labour, capital acquires a virtual veto over the ability of working populations to determine their own economic destiny through collective bargaining, even while the social provisions of the welfare state are shredded to make regions more attractive to foreign investment. Global market access mandated by international regulatory bodies and legal frameworks further wither the citizenry's control over labour laws, regulations, and trade policy. The integration into unregulated global financial markets not only enhances capital's ability to discipline labour, but also enables the disciplining of entire governments, vastly reducing the spectrum of possible policy options. Critically, the institutions of the TSA which underpin this system are designed so as to be insulated from democratic pressure. In this way, global neoliberal flexible accumulation undermines the capacity of local populations to control their own economic, social, and political destinies. If there is some other global political-economy more toxic to the meaningful application of democratic citizenship, it does not spring readily to mind.

\subsubsection{Concentration of Wealth}

With these processes in mind it is little wonder that, as Harvey explains, the result of global neoliberalism has been to "redistribute, rather than to generate, wealth and income" (2005, p. 156-159). Contrary to neoliberal dogma, reforms have seen "stagnation or economic collapse" for early adopters like Argentina, Mexico, and Brazil. Moreover, since the 1960s "almost all global indicators of health levels, life expectancy, infant mortality, and the like show losses", while much heralded "decline[s] in global poverty appear... to be almost entirely in India and China". Simultaneously, skyrocketing international debt has seen the "equivalent of 50 marshal plans... sent" from the developing world to the core creditor countries since 1980 (p. 162).

Meanwhile, the average salary of a US CEO relative to that of their employees has increased from 30-50 times in 1970 to $200-2000$ times today (p. 18). There has been a corresponding concentration of wealth amongst the global rich, with the net worth of the 358 richest people equalling 
the combined income of the poorest $45 \%$ of the world's population in 1996 , and the net worth of the 200 richest people more than doubling between 1994 and 1998 (p. 34).

Yet despite these catastrophic results neoliberalism maintains its position as the dominant economic ideology of our society, with virtually no dissent from the mainstream press or the large think-tanks. Though "the flows of tribute into the world's major financial centres have been astonishing", notes Harvey, "the very idea that this might be... the fundamental core of what neoliberalism has been about all along appears unthinkable" (p. 118). This is a perfect example of a ruling ideology in the Marxist-Gramscian sense - one which presents itself as natural, inevitable, and broadly beneficial even while maintaining the interests of dominant class formations. Yet the efficacy of neoliberalism - both its ideational appeal and its practical application - would be virtually impossible without the rise of informationism.

\section{Informationism and the Technology of Neoliberalism}

Informationists have made much of the decline of labor, the erosion of manufacturing, the rise of information networks and symbolic economies, and the ascension of a technologically reified global economy, which despite the pains of transition are all seen as indicators of a coming techno-utopia. That these changes are described as technologically induced not only obscures the political intervention of neoliberalism and its hegemonic aspirations, but also helps form the basis of prescriptions for socio-technological changes without which global neoliberal regimes of flexible accumulation would simply not be possible.

From the beginning of capital's response to the interlocking crises of accumulation which manifested during the 1970s, high technology was seized upon as a critical resource in the pursuit of flexible accumulation as a means to transcend capitalist contradiction. This entailed massive investments throughout the 1970s, 1980s, and 1990s in ICT and new production and trade technologies on the part of both capital and governments (Harvey, 2005, pp. 157-159; Chakravartty and Schiller, 2010, pp. 672-676; Harrison and Bluestone, 1989, pp. 28-38; Thompson, 2010; Hope, 2010; Dyer-Witheford, 1999; Robinson, 2004; 2008). These investments were overtly understood by these actors as to be complementary to the emergent regime of flexible accumulation and the neoliberal ideology on which it was based, making technically feasible what the neoliberal regime made legally possible. In many respects, notes Harvey, ICT "is the privileged technology of neoliberalism" (2005, p. 159), as it is absolutely crucial in managing the integration and coordination of financial and productive systems under a global market. Indeed, such a system requires the capacity "to accumulate, store, transfer, analyze, and use massive" quantities of information to "guide decisions in the global marketplace" as well as to coordinate transnational investment, financial, production and trade flows (p. 3).

In fact, informationist rhetoric of the rise of 'symbolic economies' are in no small part glorified descriptions of the consolidation of the global telecommunications networks "required by market driven financialisation". Global financial markets are by their very essence symbolic economies, only rendered feasible by technologies that enhance capital and financial mobility (McGuian, 1999, p. 108) through the dramatic reduction of communication costs and transfer times (Harvey, 2005, p. 92). In fact, the establishment of global financial networks was fundamentally dependant on the development and proliferation of ICT networks (Robinson, 2004), (Robinson, 2008), (Hope, 2010), (Thompson, 2010). Notes Dyer-Witheford, the way in which ICT "accelerates financial flows..., permit[s]... round the clock investment activity, reduc[es]... the cost of transfers [and] creat[es] a common digital medium for transaction" forms the basis of a robust global financial network (1999, p. 12-13). As already discussed, the establishment of a system in which global capital can move in and out of countries with ease, inflating or devaluing local assets at incredible speeds, is essential to the neoliberal goal of undermining the Keynesian state in favor of global regimes of flexible accumulation. The mass capital flights that destabilised East Asia, Latin America, and now the advanced West, paving the way for the transfer of wealth to a global elite and the imposition of market discipline on national governments, simply would not be possible without the global telecommunications networks which underpin global finance. 
The societal changes so enthusiastically endorsed by the informationists also help serve the neoliberal agenda by eroding the power of organised labour on a global scale. In the shift from factory labourers to knowledge-based professions and services, notes Kumar, informationists "take as a general pattern of work the conditions in the most attractive and prestigious parts of the service sector" (mass media, advertising, small professional agencies, IT, education, etc.), focusing on those workers "at the top of the hierarchy" $(1995$, p. 26). Yet the "vast bulk of expansion in these fields has been at their lower ends", with most positions being "less skilled, lower paid, less unionised, and less secure than in manufacturing" (Kumar, 1978, pp. 206-211). As Dyer-Witheford explains, "the bulk of employment in the information economy" is made up of retail clerks, cleaners, janitors, security guards, and food service workers - all of whom suffer low pay with few or no benefits, thereby maximising corporate profit at the expense of organised labour (1999, p. 96).

Furthermore, since the 1970s global capital has responded to crisis with a massive investment by capitalists in labor saving technology (Harvey, 2010, p. 33; Dyer-Witheford, 1999, p. 93; Harrison and Bluestone, 1989, p. 116). This included huge investments in computerized production technologies, robotisation, automated machine tools and delivery devices, just-in-time inventory systems and numerous other innovations meant to extend automation of work and reduce reliance on skilled labor while centralizing managerial control. Though such automation was originally targeted at industrial production, the past decades have seen the same strategies increasingly applied to services and other industries. All in all, these staggering investments in high technology were critical in generating the structural unemployment necessary to drive down the total wage bill and undermine labor militancy (Dyer-Witheford, 1999, 94; Harrison and Bluestone, 1989, pp. 100125).

Abroad, the ability to coordinate global market transactions and transnational production chains required new technical systems of communication, transportation, containerization, automation, robotization, and so on which together allowed capital to 'go global'. (Robinson, 2004, 21-22). Together, advances in ICT and other technologies allowed transnational corporations to coordinate flexible production through complex networks of suppliers, producers, subcontractors, distributors, transporters, and financiers, allowing global capital to manage production flows across different continents with greater ease than ever before (Dyer-Witheford, 1999, p. 136; Robinson, 2004), (Robinson, 2008). This has aided the neoliberal goal of shifting production to low-wage regions, as increased capital mobility allows corporations to invest in (and disinvest from) different regions more quickly and cheaply than before. Just as techno-financial networks enable the disciplining of national governments, global telecommunications networks help capital discipline labour by threatening disinvestment in search of cheaper wages, lower taxes, and weaker regulatory regimes. Technology therefore plays a major role in setting workers in competition with each other on a global scale, as newly unionised workers in Mexico or South Korea shortly find their jobs exported to Indonesia or China, or whoever next guarantees the lowest demands from labour (Harvey, 2005, p. 144).

This is why the fetishisation of information as the primary economic resource of the information age, eclipsing labour power and industrial capital, is another crucial plank in neoliberal ideology. The "symbolic" economies of global financial and telecommunications networks help internationalise production chains to better exploit cheap labour globally, even while they allow capital to discipline national governments in deregulating their own labour markets. Finally, the bulk of the working class of the developed nations, now subsumed into the service industry, remains unorganised and heavily exploited. The fact that local populations find themselves increasingly outmanoeuvred by global is glossed over by many informationists. Indeed, the emergence of a global politicaleconomy insulated from the pressures of any one region or nation was one of informationism's most celebratory pronouncements. That this emergent order is anathema to a meaningful citizenship is virtually ignored.

The fetishisation of knowledge as the "strategic" economic resource of society deftly reinforces neoliberal ideology in other ways. By implying that information - not material resources, labour, or political institutions - is the key to power in the information age, the stage is set for the downplaying 
of the citizen's emaciation under neoliberalism. As the citizenry's traditional modes of power are eroded, informationists present a glittering consolation prize of decentralised info-power exercised through technological networks. Any citizen with the technological resources to tap into the global network and manipulate 'symbolic data' is therefore a potential font of power. This lionisation of informational citizenship is particularly insidious given that it completely ignores the stunning consolidation of power in the institutions of the emergent neoliberal bloc. The WTO, the IMF, private credit agencies, financial markets dominated by large firms - all are downplayed as obsolete 'modernist' institutions. Critically, any argument to curtail the power of this bloc by imposing capital flows, regulating financial markets, or controlling currencies can be portrayed as attacks on the 'free flow of information' deemed necessary for the emergence of a utopian information age.

The reality is much less emancipatory. The same techno-financial networks glorified by informationists create the conditions for the erosion of organised labour worldwide; help instigate predatory financial crises; transfer national wealth to a global elite in the aftermath; and discipline national governments that resist neoliberal reforms. In doing so, the technology of informationism makes materially feasible what the global neoliberal regulatory system makes legally possible. And the utopian visions of both informationists and neoliberals paint this new global order, in which wealth is more concentrated and the citizenry enfeebled, as not only inevitable but eminently desirable.

This formulation is not a left-wing variant of informationism's technological determinism. The neoliberal agenda of globally deregulated labour markets would be impossible without telecommunications technologies, but equally so without the ascension over the past 30 years of a global neoliberal regulatory structure which has eroded 'barriers to trade' in capital, financial, and labour. Technology and institutional consolidation go hand-in-hand in maintaining an ideological front whose core rationale is the promotion of a neoliberal bloc which erodes the citizenry's capacity to control their own lives.

\subsection{Informational-Neoliberalism, Ideology, and Hegemony}

It should be evident by now that the similarities between neoliberalism and informationism are profound. However, it is necessary to go beyond such surface similarities to explore how the two theories function together as part of a hegemonic system, underpinned by both coercion and consent. Both these tendencies are partially dependent on the ideological front of informationalneoliberalism. On one hand, coercion results from the disciplinary power which accrues to global capital in a regime of flexible accumulation constituted by informationist and neoliberal reforms. On the other hand, consent is gained through the legitimation of those same ideological constructs in the public discourse. Finally, that legitimation becomes further reinforced by the coercive discipline imposed under the system originally planned under the rubric of the ideology itself.

Since Gramsci, much scholarship has gone towards further refining our conceptions of ideology, generally defined as a loosely-coherent system of worldviews, narratives, values, and norms used to justify, challenge, and/or interpret a given social and political order, often by invoking an ideal vision of the social world (Taylor, 2000), (Carvahlo, 2007), (Lakoff, 2010). Critical to this definition are frames - the metaphors, symbolic representations, and cognitive heuristics embedded within an ideology which together constitute an ideological system (Lakoff, 2010). As demonstrated by cognitive scientists like George Lakoff, human cognitive rationality is indivisible from the frames which mediate our understanding of facts and events (2009, p.39). Our understanding of any factual claim is therefore dependant on those systems of frames - narratives, metaphors, value systems, etc. - we use to interpret the social world (p. 68). As a single frame's activation sets off other related frames in the same system, such activation strengthens the coherence of the system as a whole (Lakoff, 2010, p. 72). Since ideologies can be understood as systems of interrelated frames which together form a loosely consistent interpretive framework for the social world, repeated exposure to ideological language will activate and eventually strengthen the systems of mutuallyinterlocked frames that make up the entire ideological system. This phenomenon may be aided by the process of frame alignment, or the discursive linking of novel ideological frames to those frames already accepted by a given individual (Taylor, 2000). If the frameworks of the ideological 
system become the dominant ones through which most individuals interpret the social world, they become reified as the 'common sense' of a hegemonic system.

It is precisely this process of frame alignment which explains the eventual linkages formed between neoliberalism and informationism as interlinked components in a global hegemonic project, functioning both to plan the emergent system and legitimize its rule. As we will see in the following section, neoliberalism and informationism both had a common heritage, emerging from a dominant bloc of elite-led civil society, state, and corporate actors in the capitalist core. This dual emergence largely owed itself to a common neoliberal class project to overcome the erosion of upper class rule and crises of capital accumulation facing the global capitalist system in the 1970s (Harvey, 2005; Harvey, 2010; Dyer-Witheford, 1999). This project saw in the combination of the two theories the possibility to reorganize national political economies around a global neoliberal regime of flexible accumulation jointly underpinned by new technologies and neoliberal reform.

Such a theoretical combination is not entirely surprising. Capitalist ideology, and neoclassical economics in particular, have long established a privileged space for technology as a 'prime mover' of capitalist growth (Harvey, 2005), (Harvey, 2010). Partially this results from the central importance of technological development in the reorganization of the means and modes of production, with new technological 'fixes' historically relied on to overcome potential barriers to capital accumulation. With this underlying systemic logic in mind, it is important to recall how the reforms of both informationism and neoliberalism were mutually necessary for the establishment of a global regime of flexible accumulation. A globally integrated market system was a mere pipe dream without the ICT and transportation networks to 'stitch' the system together, while the rise of a globally integrated techno-market system was impossible without widespread neoliberal reforms which removed regulatory barriers to global capital flows. Hence the establishment of the new system depended on a mutual promotion of neoliberalism and informationism as part of a common class project.

This mutual promotion largely rested upon the mutual activation of parallel neoliberal and informationist frames through a discourse which naturalized their perceived holistic interdependence. The prolonged repetition of these frames side by side eventually resulted in a coherent, unified ideological construct, which I term informational-neoliberalism. Under this ideological construct, the technological networks of the information age and the economic networks of the 'free market' become so conflated, it becomes difficult to draw on the frames of one without activating the mutually interlinked frames of the other. Ultimately then, both sides reinforce the intellectual coherence of the totalizing whole.

The key to this ideological coherency is the repeated activation of the key frames which form the basic referents of both informationism and neoliberalism. As already noted, these referents show remarkable parallels in their visions of social change which facilitate the process of frame alignment. Common referents include: the potential production of unlimited wealth, either through market forces or information economies; the decline of 'modernist' institutions such as organized labor and the interventionist-state; the rise of a radical, post-institutional individualism; the global nature and teleological inevitability of this technologically/economically deterministic social change and a refusal to admit its political contingency. The end result is a kind of mutual reciprocity of neoliberal and informational discourse. When talking about free markets, informationist-neoliberals draw on explicitly or implicitly- the technological claims of informationism. Similarly, informationist arguments and predictions implicitly or explicitly draw on neoliberal frames. Finally, informationistneoliberal discourse has the advantage that, as informationist and neoliberal policies, reforms, and investments become increasingly consolidated, such rhetorical conflation becomes increasingly representative of the very real mutual interdependence of technology and markets under global neoliberal flexible accumulation. Free markets and the information age are assumed to be one and the same. 


\subsubsection{Informational-Neoliberal Ideology and Hegemonic Planning}

According to Gramsci, the production of a coherent ideological front by the 'organic intellectuals' of dominant civil society organizations was one of the core components of a successful hegemonic bloc. Crudely stated, this front performed two crucial hegemonic functions: planning and legitimation. As noted, Gramsci argued that under capitalism, the bloc's organic intellectuals were increasingly technocratic, acting as material organizers of the bloc's regimes of accumulation and helping to develop its emergent forms and strategies. In this way, 'organic intellectuals' perform a key planning role for the bloc as they rationalise and delineate its emergent structure.

Such was the case with neoliberalism, in which intellectuals in different countries helped develop the blueprints for the reforms which constituted the emergent TSA. Often these efforts emerged from corporate- and state-backed think tanks and policy institutes in which neoliberal intellectuals helped develop and propagate reforms subsequently adopted by their various countries of origin (Desai, 1994; Robinson, 2004; Robinson, 2008; Harvey, 2005; Stone, 1996; Gutstein, 2009; Stefancic and Delgado, 1996; Fischer, 1991; Rich, 2004). In other cases, neoliberal academics, government and corporate planners, and policy entrepreneurs - often trained in the major academic, civil society and economic institutions of the capitalist core - directly worked for governments around the world to develop the reforms for the neoliberal transition (Klein, 2007; Robinson, 2004; 2008).

The rise of informationism followed a similar course. Dyer-Witheford notes that, like neoliberals, informationists "did not merely describe the future... they prescribed it" $(1999, \mathrm{p}$. 22). This is to say they performed a similar planning function to their neoliberal brethren - and indeed, were sometimes indistinguishable from them. Like neoliberalism, informationism was "formulated and promoted within the think tanks, policy institutes, laboratories, government offices, and consultancy circuits of the most powerful and prosperous centres of the capitalist world economy" (p. 17). Some of the first major formulations of the theory came out of Ivy League institutions, IBM-sponsored conferences, the right-wing Rand Corporation, the US government, and numerous corporate studies, only to be vigorously promoted by the corporate press. In this sense, the original informationist planners can be understood as intellectuals 'organically` integrated into the major institutions of the emergent neoliberal bloc.

Informationist reform first became a major government initiative in Japan during the 1960s, when the Japanese bureaucracy incorporated Yonei Masuda's ideas of the 'information age' into their national development strategies for overcoming that decade's perceived crisis of developmental economics (p. 20). In short time, these ideas had been seized on in North America and Europe, where "interest in these ideas was accelerated by [the] economic recession" of the 1970s. What followed was the rapid and expansive embrace by government agencies, academic institutes, and corporate planners of 'post-industrial' planning strategies of "computerisation, robotization, workplace reorganization, and systematic 'softening' of the economy".

Notes Dyer-Witheford, "by the late 1970s, the 'information revolution' was emerging as a central category in government and corporate planning" (p. 21). It's currency increased during the 1980s, popularised by a "spate of similar academic studies; by best-selling popularisations such as Alvin Toffler's The Third Wave and John Naisbett's Megatrends; by a burgeoning business literature devoted to managing in the information age; and by journalistic coverage of the type that made the microcomputer Time's Person of the Year' for 1982". Together, "all of this translated theories of the information revolution into a popular idiom of the 1980s".

Importantly, the theories of Daniel Bell and Yonei Masuda had considered governmental bureaucracy a central actor in bringing on and managing the post-industrial future. Meanwhile, the informationists of the 1970s, 1980s, and 1990s had become "more attuned to the climate of Thatcherism and Reaganism", largely rejecting the Keynesian state in favour of a market-led information-age structured around neoliberal theory (p. 21). This was perhaps unsurprising, given that both neoliberalism and informationism had been embraced by the corporate and government planning community as a solution to the interlocking cries of capitalism facing the advanced capitalist core during the 1970 s. 
Critically, this new shift in informationist theory paralleled, and indeed rationalised, the massive investments in high technology by western corporations and governments who had already embraced technologically-constituted neoliberal flexible accumulation as the solution to capitalist crisis. In its new neoliberal form, "the idea of an information revolution... became a crucial intellectual and rhetorical component in a project of high technology restructuring pursued collaboratively by state and corporate sectors throughout the advanced capitalist world" (p. 22). Simply put, informationist planners increasingly pursued a vision of reform in line with a parallel project of neoliberalisation, to the point that preferred 'post-industrial' and neoliberal reforms became largely interchangeable, and were jointly pursued as an integrated response to crises of capital accumulation. What emerged was an informational-neoliberal reform project dedicated to the establishment of a global regime of flexible accumulation mutually constituted by technological development and neoliberal regulation.

To this end, a "new epoch" was "declared inevitable" while in fact hinging on concrete political decisions made in the centres of global power. Informationist planners successfully urged the US government to subsidise high-technology research, forge academic-business partnerships, deregulate phone companies, and privatise telecommunications networks in order to sheppard in the information age, which by their own admission would be an age of global finance and trade with massive shifts in industrial production and the decline of organised labour (pp. 18-22). To fail in this task would mean lost jobs and declining standards of living (a common neoliberal refrain).

For example, the fiercely neoliberal Clinton administration was an aggressive champion of informationist dogma, utilising informationist arguments to further the consolidation of global neoliberal regimes of flexible accumulation (Dyer-Witheford, 1999, pp. 33-35). In 1994 its congress passed the National Information Infrastructure Bill which initiated construction on the "information superhighway", a high-bandwidth national telecommunications network that was to be government subsidized but privately owned. Clinton's Vice President, Al Gore, made numerous speeches in which he explained that this new "national information infrastructure" could only function in an unregulated business climate.

Their political rival, arch-neoliberal Newt Gingrich, founded the Progress and Freedom Foundation which hosted "major conferences on the confluence of capitalism and the information age". The foundation eventually published the 1994 collection "Cyberspace and the American Dream: A Magna Carta for the Information Age", featuring notable informationists Alvin Toffler (who had become Gingrich's personal advisor), George Gilder, and Esther Dyson. The information age, read the Magna Carta, was not only heralding the "overthrow of matter", but was creating an economic climate that necessitated "strong intellectual property rights to protect private ownership"; telecommunications infrastructure "owned by an unregulated private monopoly"; tax breaks for high tech companies; and "the widespread dismantling of federal government regulations". Many of these recommendations found their way into the 1996 US Telecommunications Bill, which championed the role of "deregulated, concentrated capital to manage the new informational environment". Tellingly, the Progress and Freedom Foundation's list of financial supporters includes some of the most powerful ICT and media firms on the planet: Amazon.com, AOL-Time Warner, Cisco Systems, Disney, Hewlett-Packard, IBM, Intel, MGM, Motorola, News Corporation, Sun Microsystems, Viacom, and Verison Communications (Mosco, 2004, p. 108).

\subsection{Informational-Neoliberalism and Hegemonic Legitimation}

Beyond their planning role, Gramsci noted that ideologies served a critical legitimation function for hegemony, with the bloc's organic intellectuals increasingly serving as "permanent persuaders" of the public under capitalism (2005, p. 5). As noted, ideology can perhaps best be understood as a loosely-coherent system of worldviews, narratives, values, and norms used to justify, challenge, and/or interpret a given social and political order, often by invoking an ideal vision of the social world (Taylor, 2000; Carvahlo, 2007; Lakoff, 2010). Such a definition well-describes our previous descriptions of informational-neoliberalism, with its interlocking worldviews (teleological market/technology-driven social change), narratives (trends of inevitable radical social transformation), 
and values (normative desirability of these changes as benevolent, natural, and inevitable); it's challenging of old social orders (national state led development/industrial civilisation) and justification of coming new ones (the information age/the global market economy); and it's ideal visions of the social world (informational/market utopias). Together, these ideological constructs have become key parts of the 'common sense' of techno market society, and have therefore been crucial in legitimating both the perceived desirability and inevitability of the informational-neoliberal transition (Frank, 2000; 2004; Harvey, 2005; Dyer-Witheford, 1999; Gutstein, 2009).

It is therefore important to take into account the efforts of neoliberal intellectuals and activists who have worked tirelessly over the past 40 years to introduce neoliberal frames into the public consciousness, thereby legitimizing the ideological basis for hegemonic consent. They have done this through the work of corporate-backed think tanks and advocacy groups, appearances and articles in the mass media, the publishing of academic studies and popular non-fiction books, and the production of government reports and testimony (Frank, 2000; 2004; Harvey, 2005; Gutstein, 2009; Stefancic and Delgado, 1996; Lakoff, 2009; 2010). There is now a good deal of scholarly evidence that these efforts have been quite successful in shifting public opinion towards neoliberal and neoconservative modes of thought over the past 40 years, especially in North America (Lakoff, 2009; Lakoff, 2009; Jacques, Dunlap, and Freeman, 2008; Stone, 1996; Gutstein, 2009; Stefancic and Delgado, 1996; Rich, 2004; Harvey, 2005). A large part of the success of this legitimation project has occurred through strategic framing. In the public discourse, the frames of neoliberal discourse have often been aligned with other, already widely accepted frames, especially those related to individual freedom and liberty, conservative populism and anti-elitism, democracy, religious values, and other prominent conceptual systems of thought.

\subsubsection{Informational-Neoliberal Ideology and Information Populism}

Like neoliberalism, informationism has been legitimated in the public discourse over the past 30 years as societal 'common sense' through its repeated invocation and glorification by its numerous proponents, including journalists, popular writers, and corporate advertisers (Dyer-Witheford, 1999, pp. 5-30; Frank, 2000). Such activities have largely taken the form of the promotion of informational-neoliberal frames as the basis for hegemonic consent. As Thomas Frank has shown, in the United States much of these efforts to 'sell' the transition towards neoliberal flexible accumulation rested on the propagation of what he calls 'market populism' (perhaps better described as 'technomarket populism'), a recurring discursive tool and ideological construct utilized to legitimize the new hegemonic order (2000). In this ideological system, the basic precepts of informationalneoliberalism - the inevitable and natural rise of a global techno-market system which will undermine labor and the state; elimination of scarcity and production of infinite wealth through symbolic economies; and the ascendance of a transcendent individualism in the wake of a crumbling mass society - are aligned with the interlocking frames of an emancipatory democratic populist project. In so doing, the new order described by informational-neoliberals becomes legitimated through its repeated discursive alignment over time with ready popular conceptual frames, even while the interlink age of informationist and neoliberal frames themselves were strengthened through their mutual activation.

In this system, citizens are empowered to exercise their democratic preferences through their individual activities in a democratically-structured and technologically-enabled market system. In other words, "electoral democracy is... interchanged in the public discourse with democracy of the market", which is seen as a more perfect mechanism for exercising the popular will (p. 17). In doing so, they are partaking in a populist revolution, leveraging new technologies to enter the marketplace on an even playing field with elites, overthrowing the corrupt rule of the now-obsolete mass institutions of state, economy, and labor (p. 10). Remarkably, then, even as the informationalneoliberal market system withers the power of organized labor and democratic publics while further consolidating the power of global elites, citizens are assured of the arrival of a revolutionary and more meaningful democratic populist project in the form of that very same informational-neoliberal market system. 
During the 1990s, such democratic populist frames were repeated over and over by informational-neoliberalism's proponents in articles in the mass press and popular non-fiction books, promoting an emancipatory project organized around radical individualism. For example, informationist economist Lawrence Kudlow wrote in 1999 that "the internet empowers ordinary people and disempowers government" (p. 79). Similarly, informationist guru and Reagan advisor George Gilder assured readers that the informational-market system was "moving authority from elites and establishments to creators and customers" (p. 82). Meanwhile, Thomas Friedman of the New York Times explained in a 1999 op-ed that the "internet revolution" mirrored the tumbling of the Berlin Wall, stripping the power of tyrannical "governments and unions" to regulate global capital flows ( $p$. 64). In fact, the most important accomplishment of Reagan in "spurring the information revolution" was to bust the unions, thereby breaking "the hold of organized labor over the US economy".

Much of this rhetoric emerged from the pages of Wired, the market-libertarian and technofetishistic magazine which proved utterly devoted to the promotion of techno-market populism. In its pages informationist Jon Katz praised the web for its creation of a new generation of "digital citizens" whose allegiance to the inherently pro-market internet compelled them to vote in favor of further neoliberal deregulation (pp. 83-84). Meanwhile, in 1997, the magazine's $5^{\text {th }}$ anniversary issue featured writers form the fiercely neoliberal (and corporate-backed) Cato Institute, who heralded the magazine's first half-decade as the "five greatest years for humanity" (p. 85). Repeating standard informationist dogma, one editorial assured readers that "in this economy, our ability to create wealth is not bound by physical limits, but by our ability to come up with new ideas", and was therefore "unlimited". One Wired editor even wrote that the state was being replaced by the internet-enabled market as a superior "medium" for "expressing the popular will" (p. 59). Meanwhile, "futurist" Peter Schwartz wrote heavily in Wired, at one point writing a fictional Utopian piece set in the year 2020. The described utopia had been "enabled by technologically emancipated global market forces" facilitated by outsourcing, downsizing, the busting of unions, privatization, and the dismantling of the welfare state. Together, this was "the formula that eventually leads toward the new economy", in which "interactive technologies" were permitting "radically new forms of participatory democracy on a scale never imagined".

In alignment with the informational focus on 'symbolic' economies empowering a transcendent individualism, one major plank in techno-market populist legitimation was to reframe the increasing financialisation of the 'new economy' as a democratizing populist phenomenon. Indeed, the expansion of individual corporate shareholding (infinite symbolic wealth) throughout society during the 1980s and 1990s was seen as a recompense for the wage stagnation (obsolete and finite industrial wealth) experienced by most working people since the 1980s (p. 99). As stock ownership became more socially dispersed, notes Frank, techno-market populists argued that "we could slash away the welfare state, hobble the unions, downsize the workforce, send the factories to Mexico - and no one would get hurt" (p. 96). This despite the fact that, even with an increasing dispersal of stock ownership, "the vast majority of shares [were] still held by the wealthy". In fact, there is good evidence that financialisation of the economy over the past 40 years has actually been responsible for increasing income inequality, with the majority of financial gains accruing to the world's wealthiest investors and corporations (Harvey, 2005; 2010; Frank, 2000, pp. 95-98; Robinson, 2004; 2008). On top of this, the rise of globally integrated deregulated finance has been one of the key instruments of global capital used to discipline both democratic governments and organized labor, and thereby a major force in the global undermining of democratic citizenship in service of elite power.

Regardless, public intellectuals like financial historian Ron Chernow wrote of the new era of financialisation as the age of "democratic investing" (Frank, 2000, p. 122). The internet was crucial in this regard, with the rise of online stock trading, combined with online purchasing through sites like eBay, PayPal, and Amazon, seized on in media reports as evidence of a radical new form of economic populist democratization, allowing previously disenfranchised individuals to emerge as entrepreneurial capitalists (pp. 162-163). For example, Thomas Friedman argued that such developments coupled with the spread of technologically-enabled global free market systems had "turned the whole world into a parliamentary system", where citizens could "vote every hour, every 
day through their mutual funds, their pension funds, their brokers, and more and more, form their own basements via the internet" (p. 93). Meanwhile, a 1996 Business Week article argued that the "flood of money into equities" represented "a transfer of wealth form the corporation to the individual", with "the big market gains...going to the little guys" (p. 123).

The advertising of online brokerages and traditional financial corporations similarly aligned the frames of techno-finance with those of democratic populism and radical individualism. One mutual fund aired advertising featuring footage of FDR signing the Social Security Act of 1935, claiming that "today, we're picking up where he left off" (p. 102). Fund manager Charles Schwab advertised his online brokerage claiming that "this internet stuff is about freedom. You're in control" (p. 91). Meanwhile, the online brokerage E-Trade aired an advertisement in 1999 that harkened back to the successive "revolutions" of the $20^{\text {th }}$ century: desegregation and women's rights. "From one revolution to the next", E-Trade would prove those wrong who "said there were haves and have nots". After all, "in the $21^{\text {st }}$ century it's about leveling the playing field and democratizing individual personal financial services". Another E-Trade ad depicting Wall Street as corrupt and elitist, assured its potential customers that now, by trading online, "the power is in your hands" (p. 89).

Importantly, the period of intensified techno-market populist legitimation described by Frank occurred mostly during the 1990s, before the bursting of the tech bubble in 2001. After that, it seems that there was a notable decline in such rapturous promotion of the utopian techno-market order (though it should be noted that this occurred long after many of the neoliberal reforms advocated by informational-neoliberals were well in place and institutionally consolidated). One might expect a further demystification of global informational-neoliberalism following the 2008 global financialeconomic crisis, when deregulated and globally integrated financial industries combined with decades of rising debt resulting from outsourcing and deindustrialization to collapse the global economy, decimate assets, and throw national finances into chaos (Harvey, 2010). Furthermore, it has since been shown that the advanced ICT networks which constitute the financial system were a key driver of the collapse itself, helping to generate crisis, collapse asset values, and propagate the catastrophe across national borders at near instantaneous speeds (Chakravarty and Schiller, 2010; Hope, 2010; Thompson, 2010).

Yet in some circles, the emancipatory framing of informational-neoliberalism is very much alive. Take In the Next Industrial Revolution, Atoms Are the New Bits, a 2010 lead article in Wired by Chris Anderson which overtly relies on techno-market populist frames to promote an emancipatory informational-neoliberalism, specifically the rise of flexible, globalised production chains made possible through new ICTs and integrated global markets (2010). In the article, Anderson giddily exalts the development of new ICT-enabled development tools such as "3-D design software", "photorealistic rendering technology", small-batch "electronics assembly", and "3-D printing" which are making "the tools of factory production... available to individuals". In fact, "manufacturing [itself] has been opened up to individuals", as the rise of ICT-enabled global supply chains embedded in free markets allow these new entrepreneurs to "scale prototypes into full production runs". This occurs through new, flexible forms of outsourcing, as individuals gain access to a "new world of openaccess factories in China". In fact, the steep drop in demand and deflationary price spirals produced by the 2008 global financial crisis have compelled Chinese manufacturers to "handle small orders more efficiently", with "factories increasingly tak[ing] orders online, communicat[ing] with customers by email, and accept[ing] payment by credit card or PayPal". In short, "anybody with an idea and a little expertise can set assembly lines in China into motion with nothing more than some keystrokes on their laptop".

All these trends are seen as eminently emancipatory, even revolutionary, framed as they are within the context of the democratic populist potential of informational-neoliberalism. Argues Anderson, in "democratiz[ing] manufacturing", "every garage" becomes "a potential micro-factory" and "every citizen a potential micro-entrepreneur". In fact, with "everybody's garage...a potential high tech factory", the means of production have become so widely available that even "Marx would be pleased". 
As usual, informational-neoliberal utopia represents the transcendence of the individual from the oppressive bonds of obsolete institutions of state, corporation, and labor:

"If the past 10 years have been about discovering post-institutional social models on the Web, then the next 10 years will be about applying them to the real world... Transformative change happens when industries democratize, when they're ripped from the sole domain of companies, governments, and other institutions and handed over to regular folks. The Internet democratized publishing, broadcasting, and communications, and the consequence was a massive increase in the range of both participation and participants in everything digital - the long tail of bits. Now the same is happening to manufacturing - the long tail of things... The garage is fine for limited production, but if you want to go big, go global - outsource. Factories in China are standing by..."

However, it is not just deunionised labor in China one can exploit in this confused, emancipatory project - free labor can be leveraged right at home, integrated into flexible production systems which transcend the old, clumsy Fordist production systems of mass society. Anderson enthusiastically describes an "open source car company" in which the design for new vehicles are "crowdsourced" to volunteer designers on the web. This "process [is] no politburo", but "a competition" between enthusiastic volunteers with a "refusal to design just another car, compromised by massmarket needs and convention". Importantly, the company "can take a new vehicle from sketch to market in 18 months, about the time it takes Detroit" - the seemingly eternal symbol of clumsy, unionized, mass production - "to change the specs on some door trim". Furthermore, the small batch design and production process "exempts the vehicles from many regulatory restrictions", producing a vehicle that "puts Detroit to shame".

The key to this process is free labor, as the decline of the North American auto industry means that "less than 30 percent of car design students get jobs at auto companies upon graduation". "The rest become frustrated car designers, exactly the pool of talent that might respond to a wellorganized vehicle design competition and community". In fact, the company's "Web site has around 5,000 members", representing a "500-to-1 ratio of volunteer contributors to employees." After all, why would a company want to "turn to the person who happens to be in the next cubicle when it's just as easy to turn to an online community member from a global marketplace of talent?" This is "the new industrial organizational model...,built around small pieces, loosely joined". It is composed of "companies [that] are small, virtual, and informal", and in which "most participants are not employees"

In the pages of Wired, the informational-market populism identified by Frank seems very much alive, promoting the new possibilities opened up by advanced ICT networks embedded in an integrated free market system. Emancipation is envisioned as a radically individualistic affair, with individuals using technology to leverage the benefits of global flexible accumulation and democratize the very process of production. In so doing, every tech-savvy individual becomes a potential capitalist - a regular claim of techno-market populist rhetoric. Importantly, these new micro-capitalists can flee not only excessive regulatory burdens, but also the obsolete institutions of state, corporation, and organized labor. At the core of this new (and improved) democracy is the capacity for ordinary individuals to use advanced ICTs to exploit the neoliberal regime's networks of globally integrated production-supply chains, especially de-unionised Chinese labor (whose own prospects for democracy- whether political, informational, or market oriented, are not addressed). Even the structural unemployment generated by global flexible production is spun through an emancipatory framing that glorifies the production of a reserve army of 'volunteer' labor from which populist micro-capitalists can extract obscene levels of surplus value. Paradoxically, Marx is meant to be pleased with a system that allows it easier than ever before for those with the requisite capital to exploit de-unionized and even free labor, whether at home or abroad. This new state of affairs has been facilitated by both structural unemployment and the 2008 crisis, so that even the catastrophes produced by a system of global flexible accumulation are framed through democratic populist rhetoric as a sign of the further emancipatory potential of that same system! 
Another remarkable Wired article from the same year shows that such techno-market populist framing was no isolated affair. In Money Wants To Be Free, Daniel Roth similarly expounds the virtue of new ICTs embedded in global neoliberal accumulation regimes (2010). This time the great emancipators are the new web-based technologies of PayPal, Google, Amazon, Facebook, and a myriad of start-up companies which are allowing for new, "friction-free" payment options and money transfers online. With these new ICTs, "moving money, once a function managed only by the biggest companies in the world, is now a feature available to any code jockey". Deregulation is the key to this revolution. Though previously "anybody who wanted to create a service like this would have had to navigate a morass of state and federal regulations and licensing bodies", now there are "no charges for moving money internationally".

The result is as new world of globally integrated and deregulated techno-finance in which new ICTs are liberating the citizenry from the repressive institutions of corporation and state. These computer designers and financiers are constantly "seeking out ways small and large to tear down the stronghold the banks and credit card companies have" created. "This is the kind of revolutionary fervor that PayPal was always intended to foment", notes Roth. "Peter Thiel, PayPal's cofounder and a die-hard libertarian, launched the company as a means of creating a stateless monetary system" so that "anyone [could]... switch, instantly and easily, between global currencies". States Thiel, "PayPal [was hoped to]... give citizens worldwide more direct control over their currencies than they've ever had before", making it "nearly impossible for corrupt governments to steal wealth from their people." Or, as a developer from a new start-up later shouts: "This is the main battleground of capitalism!"

Once again, we see a techno-market populism glamorizing technologically-enabled regimes of flexible accumulation, as new combinations of ICTs and deregulated markets empower individuals to democratize finance at the expense of traditional economic and state elites. Never mind that nearly all the new technologies discussed are either developed or financed by massive corporations and wealthy venture capitalists. What is important is the onset of an emancipatory stateless monetary system unhindered by government regulations, allowing capital to further their evasion of state control. Following standard informationist doctrine, these new developments are described as 'revolutionary'. Incredibly, a mere 2 years after a financial crisis instigated largely by global deregulation and integration of financial markets has lead to the further emiseration of the world's working classes under the heel of global finance, the continuance of these very trends are somehow presented as a populist, democratic victory.

\subsubsection{History's End, The Flat World and Market Discipline}

The establishment of hegemonic consent for neoliberal flexible accumulation through ideological legitimation does not rely on emancipatory framing alone. Importantly, the public intellectuals of informational-neoliberalism only align their arguments with the frames of democratic populism to the extent that the public's democratic populist impulses can be mediated through the technomarketplace. While the populace are expressly encouraged to pursue 'democracy' as individual consumers, investors, or producers in the 'new economy', any traditional exercise of democratic citizenship through participation in obsolete 'modernist' institutions (elected governments, trade unions, etc.) have been explicitly denigrated. When such participation threatens to interfere with the market logic of neoliberal regimes of flexible accumulation, such denigration can turn blatantly antidemocratic - in keeping with the authoritarian streak of neoliberal ideology. While empowerment is found in the technological networks of the market, traditional exercises of democratic citizenship are subject to strict techno-market discipline. In this way the legitimation strategies of informationalneoliberalism reveal themselves as a dialectical discourse - emancipatory democratic populism for those which accept the new order, and disciplinary futility and emiseration for those which resist. Framing the new order as an inevitable and unstoppable force of history, individuals are encouraged to abandon all hope of democratic alternatives to informational-neoliberal policies which will regardless bring emancipation if left to their own devices. 
In his 1999 new economy book, Building Wealth, Lester Thurlow wrote of the "inevitability" of the new global techno-market order (Frank, 2004, p. 344). As "trying to defend" previous levels of income equality had become "impossible", those still defending the welfare state "will have to adjust to the realities of a global economy". After all, "wishing for a different game is a waste of time". The New York Times' Thomas Friedman, writing in 1998 of the rejection of IMF policies by the Malaysian President during the Asian Financial Crisis, sneered: "Ah excuse me, Mahathir, but what planet are you living on? Globalization isn't a choice. It's a reality" (p. 345). Political systems around the world may as well give in to the "golden straitjacket". Kevin Kelly's 1996 book, New Rules for the New Economy, warned apocalyptically that "No one can escape the transforming fire of machines". Rather, "the net is our future..., moving irreversibly to include everything of the world". There was therefore no choice but to "side with the net". Informationist George Gilder wrote that "the laws of the microcosm are so powerful and fundamental that they restructure nearly everything else around them" (p. 346). "However slowly theory catches up with practice", the reality of informationalneoliberalism "will increasingly dominate international reality, subduing all economic and political organizations to its logic". Equipped with ICTs, the capitalist was "“no longer entangled in territory, no longer manacled to land, capital, or nationality" (p. 347). Or as Walter Wriston wrote in his Twilight of Sovereignty, the "information revolutions" had made industrial regulation obsolete, as "capital will go where it is wanted and stay where it is well treated. It will flee from manipulation or onerous regulation of its value or use, and no government power can restrain it for long" (p. 54).

Several books have emerged as key propagators of this emancipatory-disciplinary dialectical discourse. One famous example is Francis Fukuyama's hugely influential 1992 book The End of History, which claimed that the end of the cold war had seen the collapse of any reasonable alternative to neoliberalism (Dyer-Witheford, 1999, p. 32). The ability and willingness of all nations to "integrate themselves fully into the global, capitalist economic system" and "create unimagined amounts of new wealth" had rendered any ideological alternative to privatisation and free trade anachronistic, and any state interference in unregulated capitalism "in the name of economic justice" counterproductive (Fukuyama, 2006, pp. 41-42). Behind this phenomenon was the move to an era of "high mass consumption" made possible by the technological innovations of the information age (p. 91). Only those societies that embraced competitive enterprise and decentralised market decisions could achieve the technological innovation required to overcome scarcity, a reality which created an irresistible urge for "countries to accept the basic terms of the universal capitalist economic structure". Developing nations could even acquire the "most up-to-date technologies" by accepting multinational-corporate penetration of local markets, thereby leaping to post-industrial society without suffering the pitfalls of industrialisation (p. 101). In some cases, "a modernising dictatorship can... be far more effective than a democracy" in implementing the neoliberal reforms necessary for economic growth, as democracies tend to make economically irrational choices like maintaining their welfare system or legislating high levels of corporate taxation (pp. 119-123).

It is only moderately interesting that the "end of history" is essentially an updated version of Bell's "End of Ideology", and almost predictable that Fukuyama's personal history involves stints as Deputy Director of the US State Department and consultant for the Rand Corporation (DyerWitheford, 1999, p. 32). But fascinating is the way Fukuyama's informational-neoliberal position seems to celebrate the futility of the citizenry's attempt to imagine an alternative to history's 'end'. Though unlimited wealth and prosperity follow informational-neoliberal acceptance, any attempt by democratic publics to intervene in techno-market forces are met with strict discipline, and if necessary should be guarded against with authoritarian means.

Such claims did not dissipate with the 2000 collapse of the tech bubble, as evidenced by Thomas Friedman's 2005 international bestseller The World is Flat. Friedman, a widely read and respected New York Times columnist, outlines a number of social, political, and technological factors that he sees as 'flattening' the world - that is, creating a global neoliberal political economy in which all nations and people compete on a level playing field. He describes how the collapse of communism has driven all nations towards "free-market orientated governance" (2005, p. 52), a global phenomenon made possible by the "information revolution" of global telecommunications, 
computers, and the internet (p. 56). These technological "flatteners" have allowed companies to integrate various aspects of their business worldwide, making possible a globally integrated production process (seen in the outsourcing and offshoring by large corporations to low cost regions like China and India). These developments run parallel to the ascension of free trade treaties and the WTO (another 'flattener'), which make legally possible a global political economy that otherwise would only be technologically feasible (p. 114). In this environment, the "cheaper labour, lower taxes, ... and lower health care costs" of nations like China make it more attractive for "companies [to] shift production offshore [and]...integrate... their global supply chains" (p. 120). Though this global economic integration will be "wrenching for certain manufacturing workers", leading to a general disintegration of organised labour, the overall wealth created and the new jobs generated in the knowledge sector, will more than offset the pains of transition. The key to developing a competitive information-based economy will be the "competitive flattening" of neoliberal reforms: tax breaks; the maintenance of low labour costs through a dismantling of the welfare state; the privatisation of state-owned industries; massive business deregulation; elimination of tariffs; and lax labour laws ( $p$. 315). The key to successfully implementing these 'reforms' is the circumvention of democratic processes -this has been the key to China's success (p. 280). Nations which resist these reforms will face economic stagnation and lost jobs.

Once again, not only do we see the integration of informationist and neoliberal ideology, but also a denial that any alternative exists to the explanatory or prescriptive power of either. To survive in a Flat World citizens must acknowledge there is no alternative to informational-neoliberalism. All societies must accept the same reforms, regardless of the democratic wishes of its people, lest it fall before a strict techno-market discipline. The flat world - like the post-historical era - makes a mockery of the very notion of democratic citizenship, insulated as it is from the rule of the citizen.

It is fitting then that the creeping conflation of informationism and neoliberalism has resuscitated the fundamentals of Bell's original thesis. Both ideas reject any meaningful alternative to advanced capitalism through an exercise of democratic citizenship. Admittedly, the advent of neoliberalism has seen the demonization of the welfare state and trade unionism, both key components to Bell's formulation of post-ideological stability. That said, in Bell's framework these merely served to promote stability by redistributing the wealth generated by technologically-driven advanced capitalism; in neoliberal ideology, technologically-driven advanced capitalism is the mechanism for an equitable distribution of wealth. Unions and welfare states are now unnecessary. And neoliberal ideology is buttressed by a celebratory informationism which claims that power will be decentralised through technological development, so strong labour and nation-state institutions are not only unnecessary, but anachronistic. As we have seen, these two planks in a common ideological front have become so conflated that it is increasingly difficult to tell them apart at all.

\subsection{Informational-Neoliberalism, Hegemony, and Systemic Discipline}

As the preceding accounts imply, the legitimation of informational-neoliberal ideology does not necessarily succeed because such accounts are wholly untrue. Quite the opposite. As Andrew Feenburg, paraphrasing Foucault, argues, "modern forms of oppression are based not so much on false ideologies as on the specific technical 'truths' that found and reproduce the dominant hegemony. So long as the contingency of the choice of 'truth' remains hidden, the deterministic image of a technically justified social order is projected (2010, p. 18)".

A similar framework was laid out by Herbert Marcuse, who identified the "one-dimensionality" of modern hegemony's ideological basis. Argued Marcuse, "the impact of progress turns Reason into submission to the facts of life, and to the dynamic capability of producing more and bigger facts of the same sort of life" (1991, p. 254). Under such a system, modern ideology serves hegemonic projects by "contain[ing] no facts which do not communicate the repressive power of the whole", causing individuals to find themselves "accepting... the law of their society". In such a hegemonic system, "there is only one dimension, and it is everywhere and in all forms". Individuals thereby find themselves confronted by and ultimately subsumed into an established "universe of facts" which 
deterministically and teleologicaly describe - and thereby justify - the dominant social order as the only one possible, eschewing the political contingency of that very order.

The articulations of Feenburg and Marcuse well describe the hegemonic legitimation project of informational-neoliberal ideology, which is ultimately reinforced by the very real experiences of individuals living in a social order constituted by global neoliberal regimes of flexible accumulation. Importantly, the process of legitimation is mutually constituted by the hegemonic ideology's alternative function - strategic planning - as the realities with which individuals are confronted themselves emerge from the collective work of informational-neoliberalism's organic intellectual planning class. In this way the dialectical nature of the hegemonic tasks of organic intellectuals are revealed: the public intellectuals of informational-neoliberal legitimation claim the teleological inevitability and desirability of the system partially constituted by informational-neoliberal planners, with some intellectuals playing both roles.

Both the emancipatory and disciplinary legitimation claims of informational-neoliberals are based on and reinforced by the subjective interpretation of the objective realities which confront the individual under the new order. At the emancipatory end, individuals are confronted with very real experiences of global neoliberal regimes of flexible accumulation promoted by informationalneoliberalism: the increasing integration of ICTs into everyday life, the rise of online investing and purchasing, the proliferation of social networking technology and personal communications devices, the social expansion of stock ownership, etc. Surely these experiences can be perceived as legitimately empowering, helping produce public 'buy in' for the ideological worldview of informational-neoliberals. On the other end, warnings against futile resistance to the new order by Gilder, Friedman, Fukuyama and others are reinforced by the equally real experiences of techno-market discipline which also confront the citizenry: forced austerity, capital flight and deindustrialisation; erosion of the welfare state and job security; discipline of labour and democratic states by hypermobile global capital; the devastating, transnational, and near-instantaneous effects of financial crises, etc. These disciplinary moments and processes reinforce a presumed teleological inevitability which warns of the futility and harsh punishment met by any democratic citizenship which seeks to intervene in techno-market forces, as exercised through actual public participation in democratic politics or organized labour. In this sense, the 'coercion' and 'consent' in Gramsci's model of hegemony become mutually constituted: the coercive nature of the system of neoliberal flexible accumulation reinforces the 'common sense' ideological claims of informational-neoliberalism, even while those claims help individuals interpret that same system.

Hence, the hegemonic nature of informational-neoliberal ideology reveals itself not as a wholly duplicitous falsehood, but rather as a one-dimensional propagation of the 'true' and established universe of facts at the expense of any understanding of the political contingency of those same facts, coupled with an implicit or explicit rejection of the possibility/existence of alternative truths. In other words, they take for granted as 'common sense' the novel realities of global neoliberal regimes of flexible accumulation. However, such depictions, while based on a set of socially dominant 'true' facts, also rest upon two blatant falsehoods, namely that 1) the onset of flexible accumulation under informational-neoliberalism, if accepted, will ultimately prove it's utopian and emancipatory dimensions. This claim largely ignores the documented dystopian aspects of that system; And 2) an in admission of the political-contingency of the new system, namely it's design by global elites and their intellectual allies as a class project in response to interlocking crises of global capitalism. Such one-dimensional thought reinforces a false teleology of technologically and economically determinist social change immune to social intervention, when it was exactly such intervention which constituted those changes to begin with.

None of this is to say that the experienced reality of flexible accumulation pre-empts the ideological effects of informational-neoliberalism in maintaining hegemony. Rather, the two are mutually constituted and interdependent. As Lakoff and others demonstrate, an individual's ideological frameworks mediate one's interpretation of discrete facts and events. Such has been demonstrated by the recent rise of the American Tea Party movement in the aftermath of the 2008 financialeconomic crisis. On the surface, the crisis seemed to have laid bare the blatant inaccuracies of 
informational-neoliberal ideology, resulting as it did from a crisis of effective demand following downward pressure on wages through 40 years of outsourcing, automation, and an all-around attack on labour. Such trends combined with the extreme volatility produced by globally integrated and deregulated finance to collapse global asset values by trillions of dollars while throwing the world economy into freefall, creating a corresponding crisis of state solvency.

Perhaps unsurprisingly, then, polls show that economic crisis is the number one concern of the vast majority of tea party activists (Cohen, 2010). Yet the movement, instead of rejecting informational-neoliberalism, has responded with political demands for further attacks on unions, more deregulation of finance and industry, a further embrace of harsh austerity measures, less government intervention in the economy, and the further dismantling of the welfare state ('Tea Party Leader', 2011; Fraser and Freeman, 2010; Taibbi, 2010). Furthermore, such demands have been framed through intense democratic and populist rhetoric, with heroic tea partiers seeking emancipation from the oppressive elites of state, corporations, and labour through further neoliberalisation. In other words, their interpretation of the collapse has aligned with the frames of a hard-line version of hegemonic neoliberal economic ideology and its democratic populist framing. The interpretation of events therefore seems at least partially mediated through an ideological system which those same events seem to invalidate.

It is impossible to know what direct role, if any, informationism has played in this hardline ideological response - at least without further empirical research. However, as noted, the overall vision of neoliberal ideology has long been fused with informationist theory through the propagation of popular media discourses, and it would be bizarre if the decades of business reporting, think tank literature, advertising, and best sellers by Thomas Friedman and Alvin Toffler had no effect whatsoever in this regard. Furthermore, in the ideological climate of informational-neoliberal hegemony, informationist and neoliberal claims have long become so conflated as to make it difficult to tell them apart at all, with both interlocking sets of claims reinforcing the same (flat) worldview of the natural and inevitable rule of the global market.

\section{The Global Citizen, or the Enfeebled Populace?}

Within this context, one can better understand how certain discourses of global citizenship can become entangled in informational-neoliberal ideology, thereby inadvertently legitimating the hegemonic order. This does not occur in some simple propagandic fashion, but rather through a onedimensional acceptance of the recognized universe of facts concerning technologically-constituted neoliberal regimes of flexible accumulation as societal 'common sense'. This is perhaps understandable given the central role of ICTs in constituting any type of global citizenry. As Lakoff notes, one's interpretation of the facts at hand will tend to correspond to the ideological frameworks with which one has come to associate those same facts. Hence, it is logical that some scholars who wish to explain a phenomenon - the rise of ICT-enabled global political networks and movements would come to implicitly draw upon some of the hegemonic cognitive frameworks which pertain to those same phenomena - those of informational-neoliberalism.

Unfortunately, in doing so many of the contingent 'truths' of informational-neoliberal discourse become uncritically reproduced: the central role of ICT's in radical social transformation; the withering of 'modernist' institutions and the subjectivities they produce; democratic populist emancipation through ICT-enabled inter-discursivity and - subjectivity; and, in some instances, an uncritical portrayal of a technologically-constituted global free market. What emerges is a vision of citizenship often decontextualised from the meaningful participation in public institutions which lies at the heart of traditional conceptions of democratic citizenship, especially unions and/or electoral democracy. In its place there is promoted a reliance on transnationaly interlinked discursive practices mediated by ICTs and the technologically-interlinked networks of global civil society. While it is often claimed that such models of citizenship are 'deterritorialised', it is perhaps more accurate to say they are 'deinstitutionalised'. Rarely addressed is the critical question: how can global inter-discursivity produced under global neoliberal regimes of flexible accumulation manifest itself in meaningful participation in the core institutions of the global neoliberal bloc - and not just produce a global conversa- 
tion about them? Put differently, how can global citizenship become truly and meaningfully democratic?

One sees multiple iterations of this inadvertent shortcoming in the discourses of global citizenship, though they manifest in different ways and produce differential levels of problematicity. At the most promising end lies the work of Janet Judy McIntyre-Mills, who laudably envisions global citizenship as arising from the "networks of social movements" devoted to "staying" the hand of the "supposedly rational free market" $(2007$, p. 11). To do this, globally-interlinked social movements will utilize ICTs to generate "transcultural webs of understanding" which generate new transnational intersubjectivities. This "concept of global citizenship shifts rights and responsibilities from a national to an international context", as global civil society collectively generates "social goals which are constantly redefined through dialogue" generated by the "use of computer, video, and phone technology for regular input from the full spectrum of citizens" (p. 19).

Although an excellent goal, Mclntyre-Mills seems reluctant to speculate on what institutional forms would be necessary for translating discursively generated goals into meaningful global public participation. This is particularly troubling since the dominant institutions of the global bloc which form the ascendant TSA - free trade agreements, international organizations like the World Bank, national ministries of finance and trade, etc. - have been explicitly developed so as to be insulated from democratic pressure. In short, Mcyintyre-Mills' account seems to take seriously informationalneoliberalism's claims that the new order's capacity for networked interactivity invalidates the need for direct participation in anachronistic institutions, even when it is the anti-democratic rule of those institutions which is in fact being challenged.

More problematic is the global citizenship model brought forward by Lance Bennet, who argues that "public (citizen) identities change as global economies create new personal challenges for managing careers, social relationships, and family life" (brackets in original) (2005, p. 102). Therefore, the new "cosmopolitan citizens [of]... global societies process their political choices increasingly in terms of how those choices affect their own lifestyles". As these "lifestyles become more diverse, they are poorly articulated with old political categories such as class" or "party". Hence traditional participation in public institutions is abandoned, as "effective activist political communication increasingly adopts a lifestyle vocabulary anchored in consumer choice, self-image, and personal acts of social responsibility". In other words, activism as mediated through individual participation in a market society. In particular, this involves "attaching political messages to corporate brands" in an attempt to "carry often radical idea into diverse personal life spaces, as well as across national borders and cultural divides". This formulation seems to reproduce some of the core legitimation tactics of the informational-neoliberal discourse of the 1990s: citizenship exercised as individual participation in a globally interconnected marketplace; an explicit refusal to engage with class, political parties, or any direct participation in democratic institutions, seen as obsolete in the face of a technologically constituted global free market; and activism constituted through the actions of individual consumers, not collective solidarities.

However, by far the most extreme alignment with the frames of neoliberal-informationism emerges from the global citizenship model of O'Bynre. The world, according to O'Byrne, is witnessing a shift from "participatory democracy to information society" as nation states are "broken down" by "transnational" processes of "global communication" (2003, p. 130-135). As such, "for global citizenship to have meaning,...the global state" cannot be a "functionalist" entity, but rather a "socially constructed" phenomenon. Therefore global citizenship does not involve a codified relationship to a "formal' political structure"; rather the global "state" is "actively performed by global citizens who... change the world politically every day". They do this not through any attempt at the "rational organisation of political or economic life", but through "the spread of information and information-based economies, the triumph of the image, or the potential for communication and social interaction".

O'Byrne goes on to argue that "under globalised conditions ... active participatory democracy means a discursive democracy" whose "foundations ....do not lie in institutional procedures but in...access to information". Global citizens do not exercise citizenship by participating in institu- 
tions, but by engaging in "the free flowing exchange of information" (p. 127) "on a global scale through open networking" (p. 132). Crucially, "the task of a new, global citizenship must first of all be to understand that the old-style manufacturing industries... have been replaced by industries in which the key commodity is knowledge" (p. 217). Therefore, "rather than exercising a restricted form of participation in a system of liberal democracy, we can exercise a fuller participation through... information technology and the role of global social movements" (italics added) (p. 236).

Like the End of History and the Flat World, O'Byrne's vision internalises the key assumptions of informational-neoliberalism. It revolves around a belief that the state has withered away and that as a result citizenship has been divorced from any formal control over the economic or political institutions which govern the citizenry. Instead, concrete rule over institutions is replaced with a fuller 'discursive democracy' organised around the transmission of knowledge and information. Ensuring the free flow of information through information communication technologies is therefore paramount. Also critical is a passive acceptance on the part of the citizenry that they live in an information age of decentralised power, therefore making any desire for formal control over modernist institutions anachronistic. This new age is the natural end point of a technologically determined transition to globalisation, never the culmination of a concrete political project on the part of elites.

The notion that old institutions would be replaced with a people's rule empowered by radically decentred information networks is one of the most celebrated myths of the information age. It assumes that the withering away of nation-states and organised labour is analogous to the end of the concentration of power in formal institutions. In actual fact it is precisely these types of institutions the IMF, the WTO, private rating agencies, financial firms, etc. - which have constituted the global neoliberal bloc. Far from political-economic power being decentralised, it has become concentrated in transnationalised institutions insulated from popular pressure. By ignoring this reality with images of radically diffuse networks of empowered techno-citizens, this particular strand of global citizenship discourse may unwittingly legitimate the hegemonic ideological front in two ways: 1) The emancipatory framing of the 'post-institutional' social models posited by informationalneoliberalism, as technologically-enabled interconnectivity under global neoliberal flexible accumulation is embraced as a superior substitute to democratic participation in supposedly obsolete institutions. 2) The disciplinary framing of the futility of a return to direct institutional participation in the TSA.

Like the work of Friedman or Fukuyama, the problem with these models do not emerge from the fact that they are entirely false. Rather, their problematicity emerges from their one-dimensionality - their uncritical reliance on an established universe of facts which are presented as inevitable, when in fact they are entirely politically contingent. The 'truths' they draw upon - the erosion of national democracy and labor movements, and the rise of technologically enable networks of communications underpinned by global markets - are empirically verifiable. However, by ignoring the political contingency of this state of affairs and promoting as emancipatory a discursive, informational democracy disassociated with meaningful participation in the institutions of the neoliberal bloc, these accounts - to varying degrees - ultimately align with the frames of informationalneoliberalism. They thereby reinforce the legitimacy of that profoundly anti-democratic ideological construct and the equally authoritarian global regime of accumulation it seeks to maintain and legitimate.

It would be uncharitable to portray a scholar like O'Byrne as an 'organic intellectual' in the same way as Toffler, Fukuyama, or Friedman. These latter intellectuals have been intrinsically linked with some of the core institutions of the emergent bloc, and furthermore have been integral to the processes of legitimation and articulation which have constituted it. O'Byrne, on the other hand, is a progressive Habermasian scholar who sees in the information age the potential for a genuine emancipatory project based on a technologically reified public sphere. And there are many aspects of his exploration of the connections between technology and global citizenship that are of great value. However, it is disconcerting the extent to which O'Byrne seems to internalise the key assumptions of informationist ideology as 'common sense'. It should also be noted that his account is merely the most explicit in terms of its reliance on informationist theory. Other global citizenship 
theorists seem to implicitly incorporate the same ideas, either assuming that technologicallyenabled discourse replaces meaningful institutional political participation or perhaps that such discourse will necessarily translate into meaningful political action. In doing so, they seem to set aside the larger questions of how to ensure meaningful participation in the institutions of the emergent neoliberal bloc, to say nothing of the safeguarding of the hard-won political and social rights which that bloc progressively undermines. After all, one cannot blog their way into the IMF, nor Tweet their way into Moody's Investment Services.

That said, participation and rights are only two components of classical models of citizenship another being membership in a body politic. It is much easier to reconcile this latter component with the models articulated by O'Byrne and other theorists. The information age does seem to enable membership in a transnational society for those with access to the requisite technologies. However, basing citizenship upon mere membership seems to set the bar particularly low - even many totalitarian societies could make that claim. Democratic citizenship requires meaningful participation in the political and economic affairs of a society - not for its own sake, but to safeguard the social, political, and economic rights which citizenship is meant to guarantee. Promoting informational or discursive participation in the absence of meaningful institutional participation is highly problematic, especially when political-economic power is increasingly concentrated and insulated from popular pressure in the institutions of the neoliberal bloc. In fairness, global citizenship can be envisioned without such meaningful participation; but if so, why the emancipatory claims? The answer is that these changes can only be envisioned as emancipatory when situated in the "common sense" of informational-neoliberalism.

It is not difficult to envision a meaningful global citizenship. The idea of a global citizenry leveraging technological networks to manifest a transnational civil society is an idea both powerful and attractive. Moreover, it is at least partially based on reality. From globally coordinated anti-war demonstrations to transnational activist networks fighting "globalisation", the global citizen is more than an apparition conjured up by informationists and techno-fetishists. However, proponents of global citizenship must recognize that technologically-enabled discourse is itself a poor substitute for meaningful control over the institutions which govern a society.

Hence global citizenship discourse should resist the 'one-dimensionality' of informationalneoliberalism on two levels 1 ) by rejecting the teleological and natural portrayal of the existing universe of facts which recognizes no meaningful alternative to global neoliberal regimes of flexible accumulation; and 2) when addressing the need for alternatives to this regime, by not assuming that technologically-constituted discursive practices dissociated from participation in political institutions will necessarily alter the functioning of the global system those institutions organize and maintain. In other words, they must resurrect- albeit in transnational form - the traditional conceptions of democratic citizenship which stress public participation in institutions - not just a discursive citizenship which produces argumentative positions about those institutions. It is this blindspot which has led to the most pressing theoretical errors of the global citizenship theorists discussed here - that national institutions, indeed centralised political institutions in general, have withered away in the face of globalisation. If anything, globalisation - under neoliberal regimes of flexible accumulation have made centralised political institutions more powerful than ever.

However, the most powerful institutions of today's nation state - for example ministries of trade and finance - have been (partially) subsumed into a transnational state apparatus which has been purposefully insulated from democratic political pressure. Hence, meaningful democratic global citizenship must work to formally incorporate democratic input into the institutions of the global regulatory regime - not just national ministries, but free trade agreements like NAFTA and organizations like the WTO and IMF. Indeed, these have been some of the central demands of the activist networks of the anti-globalisation movement to begin with (de Sousa Santos, 2003). Only in so far that global civil society forces such institutions to formally incorporate their input can the discursive noise generated through transnational social networks result in a meaningful, democratic, global citizenship. And only then would the political contingencies which constitute the basis of informational-neoliberalism's perceived inevitability- legalised capital flight, the removal of trade 
barriers for labour, humanitarian, or environmental reasons, flexibility of labour, etc - be laid bare for all to see.

\section{Futile or Fertile? Global Citizenship as Counterhegemonic Resistance}

The question then remains - what are the processes through which a truly counterhegemonic democratic global citizenship may emerge? As Gramsci noted, hegemony is neither monolithic nor static, but a constantly shifting constellation of social forces always open to contestation and change, especially during times of crisis when the legitimacy of the hegemonic bloc may become critically undermined $(2005$, p. 210$)$. According to his thinking, such contestation is most likely to occur through the formation of a counter-hegemonic bloc - a new, loosely aligned formation of classes and social groups collectively organized around the dismantling of the dominant hegemony and its replacement with an alternative system. Key to their success are their organic intellectuals: those individuals operating within the institutions and movements of the counter-hegemonic bloc to develop alternative ideological conceptions of the world around which movements of contestation can organize. With this in mind, we must wonder: where might we see the seeds of a counterhegemonic bloc?

Some scholars see such seeds in the internal contradictions and long-term trends of capitalism itself. In her pathbreaking work, Forces of Labor, Beverly Silver sees the possibility of a revitalised labor movement in the new centres of global manufacturing in the developing world which could eventually threaten the global neoliberal order (2003). Challenging the notions of a fatalistic raceto-the-bottom for global labor, Silver takes a long historical view to point out that, throughout the $20^{\text {th }}$ century, geographical relocation of industry to evade labour unrest has tended to produce new labour militancy and stronger workers organizations in the new manufacturing centers developed by global capital (p. 168). Also, the 'technological fixes' to crises of accumulation associated with the rise of informational-neoliberalism have produced new dynamic sectors of accumulation - such as ICTs, education, and services - likely to produce new sources of labour unrest. Importantly, the rise of 'just in time' production systems actually increase labor's structural bargaining power, as the reliance on fast-moving, flexible production chains create "increasing vulnerability of capital to disruptions in the flow of production" (p. 169). Finally, the increased transnational integration of production under global capitalism represents possibilities for a new labor internationalism as a possible challenge to global capital.

Another challenge Silver makes to pessimistic notions of global neoliberalism's continued hegemonic supremacy is the periodicity of global capitalist trends often ignored by critical scholarship. Rather than a completely novel state of affairs representing an unprecedented threat to any new challenge to global capital, Silver looks to the long duree to see in the current state of affairs the repetition of long-term trends. Beyond the periodicity of rising and falling labor militancy corresponding to geographical relocation of capital and new product lines, Silver sees the current "dismantling of the labor-friendly international regime" under neoliberalism as a repeat of the trends of the $19^{\text {th }}$ century. Like the contemporary ascendance of neoliberalism, the market movement of the $19^{\text {th }}$ century similarly saw an embrace of "laissez-faire ideology, a concerted move to free up capital from restrictions, acceleration in restructuring of global processes of capital accumulation", and a "major shift out of trade and production towards financial speculation" (p. 176). The results were similar to today: "increasing inequality, major anti-labor offenses, and a decline of labor unrest". However, the contradictions and tensions produced by this system produced a crisis of effective demand which led to the great depression and a world war, ultimately provoking increased labor militancy and democratic movements which resulted in the postwar labor-friendly global regime underpinned by Fordist production and state-led Keynesian regimes of accumulation and regulation. There is not necessarily any reason to believe, therefore, that the current activities of global capital will be any less self-defeating.

Silver does an important service in reminding scholars of the sometimes-overlooked possibilities for new labor militancy in the $21^{\text {st }}$ century, as well as the long-duree periodicity of current trends. Indeed, the possibility for new labor militancy in the face of capitalist crisis carries a great deal of 
weight following the events of 2008. However, the periodicity of capitalist development should not overshadow our understanding of the novel character of two contemporary trends under global flexible accumulation. The first is the revolutionary nature of contemporary technical means of production, especially globally interlinked networks of ICTs and new transport systems which lie at the heart of global flexible accumulation regimes. The second is the novel character of today's global neoliberal regulatory regime, organized around major institutions of the TSA - the WTO, IMF, myriad trade agreements, and globally harmonized national regulatory structures.

It is therefore problematic that Silver sees global capital's vulnerability in its embrace of 'just-in time' manufacturing, which is in fact a small component of contemporary regimes of global flexible accumulation. Beyond the capacity to simply fill small-batch orders quickly, global capital's flexible production system composed of near-instantaneous financial networks and globally-integrated, interchangeable commodity chains make capital's evasive abilities and corresponding disciplinary power much stronger than anything at its disposal in the $19^{\text {th }}$ century. Today, a work stoppage at a key Walmart supplier can be easily countered by the relatively quick and easy location of alternative suppliers in dozens of countries (Robinson, 2004; 2008; Harvey, 2005). Similarly, the expansiveness and comprehensiveness of the global regulatory regime represents a massive increase in disciplinary power of both scale and scope for global capital compared with the more limited and nationally-based neoclassical free-market regimes of the $19^{\text {th }}$ century, regardless of their similar ideological basis. Demands by labor or democratic publics for national protections from the vicissitudes of the market may be met by the threat of rapid capital flight, to say nothing of legal injunctions and other disciplinary measures from the myriad of organizations, treaties, and ratings agencies constituting the TSA (Robinson, 2004; 2008; Harvey, 2005). Therefore, reoccurring trends over decades and even centuries should not be seen as a simple repetition of history. Such trends can be qualitatively similar yet of such a quantitatively different scale that for all intents and purposes they still represent a significant break with the past. History repeats itself, but never the same way twice.

It may therefore be imprudent to place all of our hopes for a counter hegemonic challenge to global neoliberalism on the power of a resurgent global labour movement alone. More promising is a counter hegemonic democratic global citizenship organized through global civil society (with organized labour as a central component). Indeed, it is the stirrings of exactly such a movement which ignited the interest of many global citizenship theorists in the first place. Unlike the Tea Party, these will need to be organized around meaningful ideological alternatives to the dominant hegemony. These may come through the writings and media appearances of radical public intellectuals, like Naomi Klein (2007), or the proliferation of online alternative media sources, such as democracynow.org (2011) or realnews.com (2011). This sort of intellectual production helps provide alternate ideological conceptions of the world around which to organize demands and tactics. They may even be generated by the activities of transnational activists. Scholars have noted the way that the anti-globalisation movement of the 1990s and the rise of groups like the World Social Forum have produced alternative subjectivities and mental conceptions of the world to challenge the hegemony of neoliberal ideology (de Sousa Santos, 2006). Critically, all of these activities have well used new ICTs to develop the transnational generation of inter-subjectivity and -discursivity necessary to organize an international movement of diverse actors which can articulate a common set of tactics and demands- precisely as described by global citizenship scholars like Mcyintyre-Mills (2007). Such activities are rightly understood as key components of the establishment of a meaningful democratic global citizenship. As Andrew Feenburg notes, even technologies generated by corporate and state actors for ultimately oppressive purposes can be repurposed and redesigned by end-users for counter-hegemonic activities, and ICTs have proven themselves particularly open to this kind of 'secondary instrumentation' in the past (2010).

However, such movements cannot settle for a vague technologically-enabled discursive democracy formally disassociated from the institutions of global power, as global citizenship scholarship seems to imply in its most informationist form. Rather, the desire for formal inclusion in the decision-making activities of the institutions of the TSA- including the basic decision over which of 
those institutions should even be allowed to continue to exist - has been a basic goal of many in the anti-globalisation movement from the start (de Sousa Santos, 2006). Indeed, a renewal of such a movement may very well already be in the works, as evidenced by the mass mobilisations against forced austerity and further neoliberalisation in Europe in the wake of the 2008 economic crisis, especially given that these movements have directly targeted the international organizations - IMF, European Central Bank, etc. - which constitute the TSA ('Anti-Austerity Protests Hit Europe, 2010; Kuebler, 2010; France Pensions Protests Continue, 2010; Coughlan, 2010). To what extent, if any, these national movements will leverage technologically-enabled networks of communications and collaboration to generate the type of transnational civil society movement a global counterhegemonic bloc requires remains to be seen. However, crisis always provides opportunities for counterhegemonic contestation, and the current economic crisis may indeed represent just such a global opening (Harvey, 2010).

\section{Conclusion}

As a key component of the ruling ideological front, neoliberalism has become both the dominant mode of social understanding and a blueprint for a future utopia within our grasp. It is also an ideological tool for the restoration of class power on a global scale which has formed the basis of a contemporary global hegemony underpinned by regimes of flexible accumulation. It has shown this through its history: developed by radical economists, philosophers and governments in the capitalist core; propagated by a sustained corporate campaign of psychological warfare; incorporated into the most powerful regulatory institutions of the capitalist world system, etc. It has proven this also through its effects: disintegration of organised labour; elimination of barriers to accumulation; erosion of regulatory frameworks that inhibit profit; establishment of unregulated financial markets that enforce market discipline; massive concentration of wealth on a global scale, etc.

This pervasive ideology has been buttressed at every turn by informationism. Like neoliberalism, it emanated from the world's most powerful sources of corporate and government power. Its central tenets not only obscure the political goals of neoliberalism behind a veil of teleological inevitability and utopian visioning, it makes possible these very goals by uncritically promoting the technology necessary for a global neoliberal transformation. Informational-neoliberalism has thereby emerged as a core ideological component of contemporary hegemony - both as the intellectual basis for global political economic restructuring and as a legitimator of that same system through its emancipatory/disciplinary dialectical discourse. Such legitimations are reinforced by the very real phenomena which confront the citizenry under global neoliberal flexible accumulation. That the political contingency of such phenomena are obscured by the discourse of informational-neoliberlism is ironic, given that those phenomena themselves result from restructuring of the global political economy under the rubric of informational-neoliberal ideology. It is this very 'one-dimensionality' which lies at the basis of modern forms of hegemony.

With this in mind, we must remember that many strands of global citizenship discourse are profoundly intertwined with informationist dogma, based as they are on a 'one-dimensional' acceptance of the 'established universe of facts'. As such the concept, however worthy, could be in danger of being implicated in a neoliberal project whose central goal is the enfeeblement of the citizen. The end of ideology, the post-industrial society, the information age, the end of history, the flat world - they are different formulations of a common narrative thread, one in which citizenship as a form of self-rule is practically unimaginable. All point to a future/present in which alternatives to advanced capitalism are unimaginable, and exhort us to surrender to an inevitable destiny of unchallenged prosperity even while shaping that very same destiny for the benefit of the few.

\section{References}

Amin, A. (1997). Post-Fordism. Models, Fantasies, and Phantoms of Transition. In A. Amin (Ed.), Post-Fordism (pp. 280315). Oxford: Blackwell Publishers.

Anderson, C. (2010). In the Next Industrial Revolution, Atoms are the New Bits. Wired. Retrieved January 25, 2010, from http://www.wired.com/magazine/2010/01/ff_newrevolution/ 
Anti-austerity protests hit Europe: Wave of strikes and protests held in major cities and outside EU headquarters as anger over spending cuts escalates. (2010). Al Jazeera English. Retrieved September 29, 2010, from http://english.aljazeera.net/news/europe/2010/09/2010929114043842969.html

Battistoni, R. (1997). Service Learning and Democratic Citizenship. Theory into Practice, 36(3), 150-156.

Bell, D. (1973). The Coming of Post-Industrial Society. New York: Basic Books.

Bell, D. (1960). The End of Ideology. Toronto: The Free Press.

Bellamy F. J. \& Magdoff, F. (2009). The Great Financial Crisis. Causes and Consequence. New York: Monthly Review Press.

Beniger, J. (1986). The Control Revolution. Technological and Economic Origins of the Information Society. Cambridge: Harvard University Press.

Bennet, W. (2004). Branded political communication. Lifestyle Politics, Logo Campaigns and the Rise of Global Citizenship. In M. Micheletti, A. Føllesdal, and D. Stolle. (Ed.), Politics, Products, and Markets: Exploring Political Consumerism Past and Present (pp. 101-123). Transaction Publishers.

Carvalho, A. (2007). Ideological Cultures and Media Discourses on Scientific Knowledge. Re-reading News on Climate Change, Public Understanding of Science, 16, 223-243.

Chakravartty, P. \& Schiller, D. (2010). Neoliberal Newspeak and Digital Capitalism in Crisis. International Journal of Communication, 4, 670-692.

Cohen, J. (2010). What motivates the tea party? Washington Post. Retrieved May 5, 2010, from http://voices.washingtonpost.com/behind-thenumbers/2010/05/what_motivates_the tea_party.html

Coughlan, S. (2010). Students stage day of protests over tuition fee rises. BBC News.

Retrieved November 24, 2010, from http://www.bbc.co.uk/news/education-11829102

Democracy Now. Retrieved July 25, 2011, from www.democracynow.org

de Sousa Santos, B. (2006). The Rise of the Global Left. The World Social Forum and Beyond. Zed Books.

Desai, R. (1994). Second Hand Dealers in Ideas: Think Tanks and Thatcherite Hegemony. New Left Review, A, 27-64.

Dyer-Witheford, N. (1999). Cyber-Marx. Cycles and Circuits of Struggle in High-Technology Capitalism. Chicago: University of Illinois Press.

Feenburg, A. (2010). Between Reason and Experience. Essays in Technology and Modernity. Cambridge: MIT Press.

Fischer, F. (1991). American Think Tanks. Policy Elites and the Politicization of Expertise. Governance, 4(3), 332-353.

France pension protests continue before vote. (2010). CBC News. Retrieved October 21, 2010, from http://www.cbc.ca/world/story/2010/10/21/france-pension-reform.html\#ixzz1DJJVfC8Q

Frank, T. (2000). One Market under God. Toronto: Doubleday.

Frank, T. (2004). What's the Matter With Kansas? How Conservatives Won The Heart of America. New York: Henry Holt and Company.

Fraser, S. \& Freeman, B. (2010). History's Mad Hatters. The Strange Career of Tea Party Populism. New Labor Forum, 19(3).

Friedman, T. (2005). The World is Flat. New York: Farrar, Straus and Giroux.

Fukuyama, F. (2006). The End of History and the Last Man. New York: Free Press.

Gramsci, A. (1985). Selections from Cultural Writings. Edited and Translated by William Boelhower, London: Lawrence and Wishart.

Gramsci, A. (2005). Selections from the Prison Notebooks. Edited and Translated by Quintin Hoare and Geoffrey Smith. New York: International Publishers.

Gutstein, D. (2009). Not a Conspiracy Theory: How Business Propaganda Hijacks Democracy. Toronto: Key Porter Books.

Harrison, B. \& Bluestone, B. (1988). The Great U-Turn. Corporate Restructuring and the Polarizing of America. New York: Basic Books.

Harvey, D. (2005). A Brief History of Neoliberalism. Oxford: Oxford University Press.

Harvey, D. (2010). The Enigma of Capital and the Crises of Capitalism. London: Profile.

Harvey, D. (1982). The Limits to Capital. Oxford: Blackwell.

Hemingway, J. (1999) Leisure, Social Capital and Democratic Citizenship. Journal of Leisure Research, 31(2), 150-165.

Hope, W. (2010). Time, Communication and Financial Collapse. International Journal of Communication, 4, 649-669.

Hope, W. (2009). Conflicting Temporalities. State, Nation, Economy and Democracy under Global Capitalism. Time \& Society, 18(1), 62-85.

Jacques, P., Dunlap, R., \& Freeman, M. (2008). The Organisation of Denial. Conservative Think Tanks and Environmental Scepticism. Environmental Politics, 17(3), 349-385.

Kellner, D. (2003). Media Spectacle. London: Routledge.

Klein, N. (2007). The Shock Doctrine. The Rise of Disaster Capitalism. New York: Metropolitan Books.

Kuebler, M. (2010). 50,000 take to the streets in Ireland against austerity plans. Deutsche Welle. Retrieved November 27, 2010, from http://www.dw-world.de/dw/article/0,,6272518,00.html

Kumar, K. (1995). From Post-Industrial to Post-Modern Society. Cambridge: Blackwell Publishers.

Kumar, K. (1978). Prophecy and Progress. London: Pelican Books. 
Lakoff, G. (2009). The Political Mind. A Cognitive Scientist's Guide to Your Brain and its Politics. New York: Penguin Books. Lakoff, G. (2010). Why It Matters How We Frame the Environment. Environmental Communication, 4(1), 70-81.

Marcuse, H. (1991). One-Dimensional Man. USA: Beacon Press.

Marx, K. (1965). The German Ideology. New York: International Publishers.

Marx, K \& Engels. F. (2006). The Ruling Class and the Ruling Ideas. In M. Durham. \& D. Kellner. (Ed.), Media and Cultural Studies Keyworks (pp. 9-12). Malden: Blackwell Publishing.

McGuian, Jim. (1999). Modernity and Postmodern Culture. Buckingham: Open University Press.

McIntye-Mills, J. (2007). Global Citizenship and Social Movements. Taylor and Francis.

Mettler, S. \& Soss, J. (2004). The Consequences of Public Policy for Democratic Citizenship. Bridging Policy Studies and Mass Politics. Perspectives on Politics, 2, 55-73.

Mosco, V. (2004). The Digital Sublime. Cambridge: MIT Press.

Nolan, P. \& Zhang, J. (2010). Global Competition After the Financial Crisis. New Left Review. (64) Retrieved from http://www.newleftreview.org/?view=2854

O'Bryrne, D. (2003). The Dimensions of Global Citizenship. Political Identity Beyond the Nation State. London: Frank Cass.

Peck, J. \& Tickell, A. (1997). Searching for a New Institutional Fix. The After-Fordist Crisis and the Global-Local Disorder. In A. Amin, (Ed.), Post-Fordism (pp. 280-315). Oxford: Blackwell Publishers.

Pozzolini, A. (1970). Antonio Gramsci. An Introduction to his Thought. London: Pluto Press.

Reed, D. (2002). Resource Extraction Industries in Developing Countries. Journal of Business Ethics, 39(3), 199-226.

Rich A. (2004). Think Tanks, Public Policy, and the Politics of Expertise. Cambridge: Cambridge University Press.

Robinson, W. (2004). A Theory of Global Capitalism. Production, Class, and State in a Transnational World. Baltimore: Johns Hopkins University Press.

Robinson, W. (2008). Latin America and Global Capitalism. Baltimore: John Hopkins University Press.

Roth, D. (2010). Money Wants to be Free/The Future of Money. It's Flexible, Frictionless and (Almost) Free. Wired. Retrieved February 22, 2010 from http://www.wired.com/magazine/2010/02/ff futureofmoney

Schattle, H. (2008). The Practices of Global Citizenship. Lanham: Rowman and Littlefield Publishers.

Silver, B. (2003). Forces of Labor. Workers' Movements and Globalization Since 1870. Cambridge: Cambridge University Press.

Stefancic, J. \& Delgado R. (1996). No Mercy. How Conservative Think Tanks and Foundations Changed America's Social Agenda. Philadelphia: Temple University Press.

Stone, D. (1996). Capturing the Political Imagination: Think Tanks and the Policy Process. London: Frank Cass.

Taibbi, M. (2010). The Truth About the Tea Party: Matt Taibbi takes down the far-right monster and the corporate insiders who created it. Rolling Stone. Retrieved September 12, 2010 from http://www.rollingstone.com/politics/news/matttaibbi-on-the-tea-party-20100928

Taylor, D. (2000). The Rise of the Environmental Justice Paradigm. Injustice Framing and the Social Construction of Environmental Discourses. American Behavioral Scientist, 43(4), 508-580.

The Real News. Retrieved July 25, 2011, from www.therealnews.com

Thompson, P. (2010). Convenient Fictions: A Critical Communication Perspective on Financial Accumulation, Autopoeisis and Crisis in the Wake of the Credit Crunch. Presented at the Annual Conference of the International Association for Media and Communication Research, Braga Portugal.

Tea Party leader calls for repeal of Dodd-Frank. (2011, Jan 5). Thompson Reuters. Retrieved January 5, 2011 from http://newsandinsight.thomsonreuters.com/Securities/news/2011/01_-_january/tea_party_leader_calls_for_repeal_of dodd-frank/

Toffler, A. (1980). The Third Wave. New York: William Morrow and Company.

Webster, F. (2006). Theories of the Information Society. New York: Routledge.

\section{About the Author}

Robert Neubauer

is currently working towards a Ph.D. in Communication at Simon Fraser University. His thesis explores the role of transnational think tank networks in underpinning global neoliberal hegemony. He earned a B.A. in Political Science (2009) from the University of British Columbia in Vancouver, Canada. He also does policy work, research, and analysis for the Social Policy Division of the City of Vancouver. 